
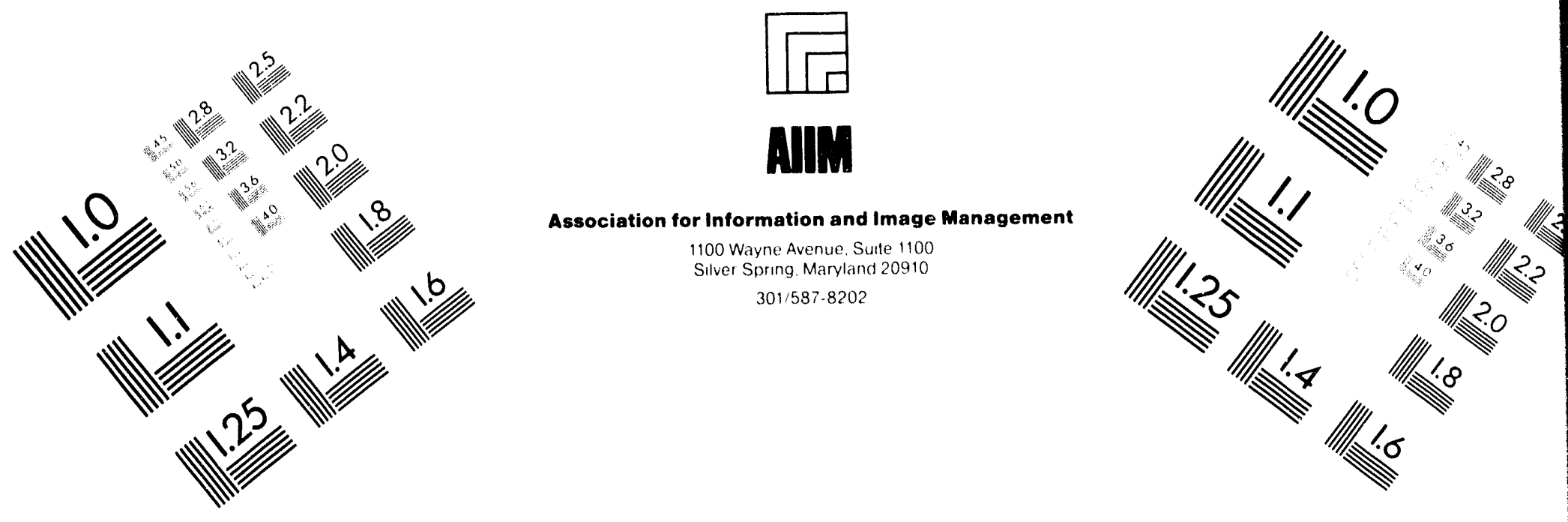

\title{
Centimeter
}

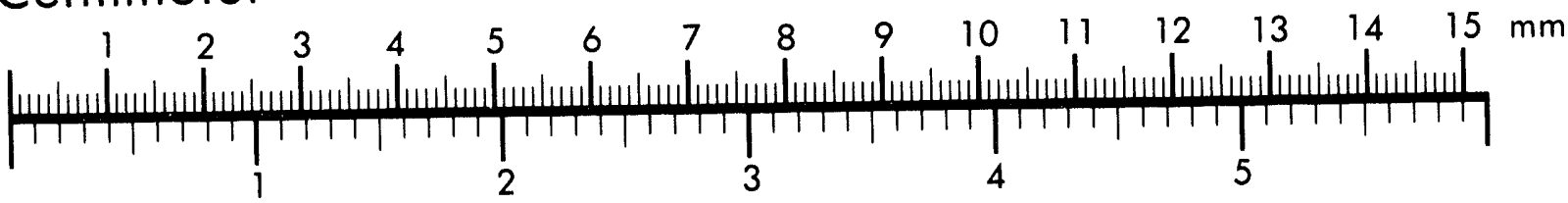

Inches
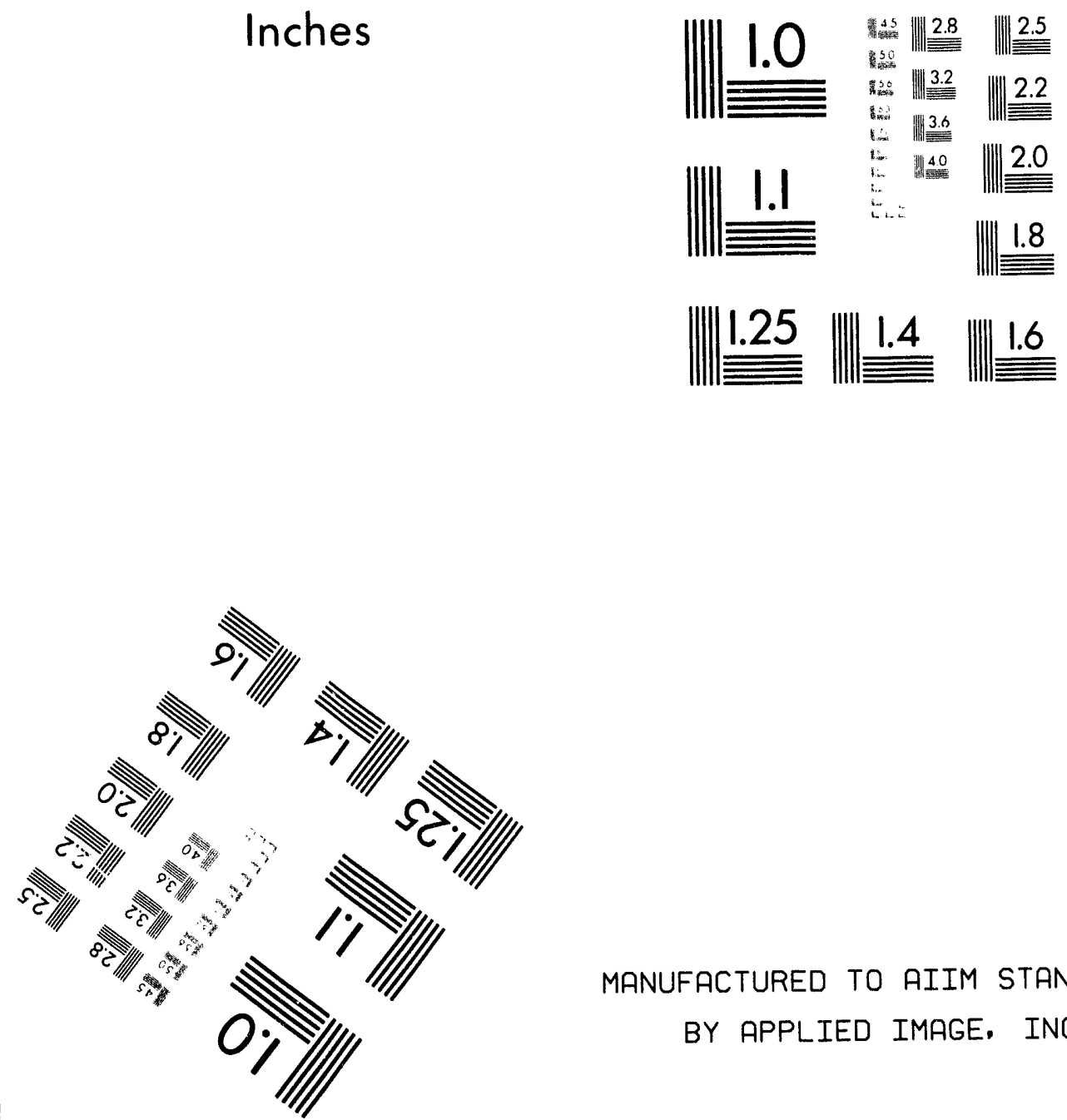

MANUFACTURED TO AIIM STANDARDS

BY APPLIED IMAGE. INC.

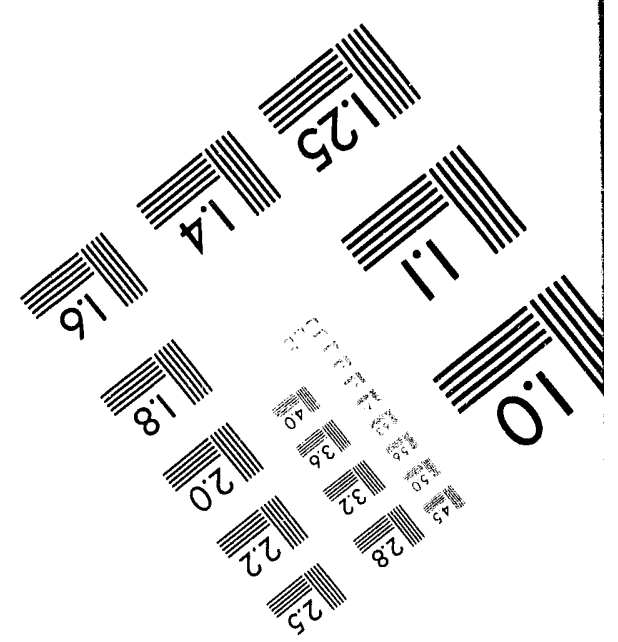



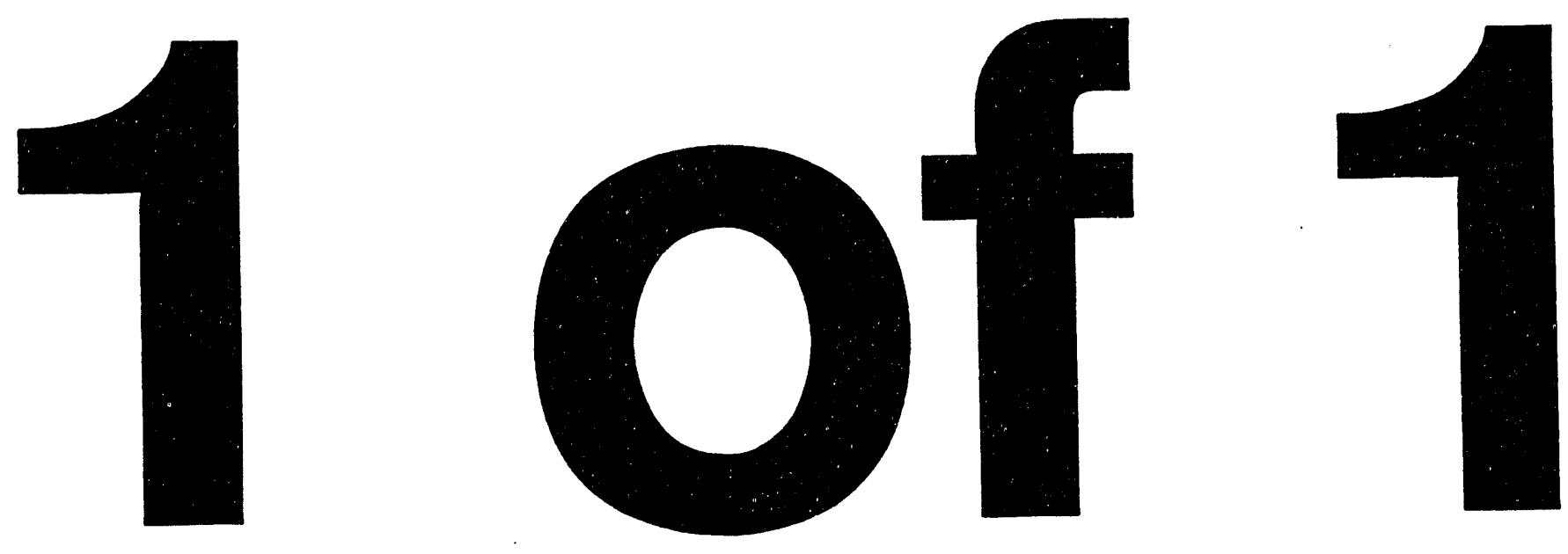


\section{A/M AREA GOUNDWATER CORRECTIVE ACTION SOUTHERN SECTOR REMEDIATION TECHNOLOGY ALTERNATIVES EVALUATION}

by

Looney, B.B.

Westinghouse Savannah River Company

Savannah River Site

Aiken, South Carolina 29808

Phifer, M.A.

This paper was prepared in connection with work done under the above contract number with the U. S.

Department of Energy. By acceptance of this paper, the publisher and/or recipient acknowledges the U. S. Government's right to retain a nonexclusive, royalty-free license in and to any copyright covering this paper, along with the right to reproduce and to authorize others to reproduce all or part of the copyrighted paper. 
WSRC-RP-94-607

\begin{abstract}
A/M Area Groundwater Corrective Action Southern Sector Remediation Technology
\end{abstract} Alternatives Evaluation (U)

June 30, 1994

B. B. Looney

M. A. Phifer

Westinghouse Savannah River Company

Savannah River Site

Aiken SC 29808

Prepared for the U. S. Department of Energy under Contract No. DE-AC09-SR18035. 


\section{Disclaimer}

This report was prepared by Westinghouse Savannah River Company (WSRC) for the United States Department of Energy (DOE) under Contract No. DE-AC09-89SR18035 and is an account of work performed under that contract. Every effort was made by the authors to assure the accuracy of the contents and interpretation. However, neither the DOE, nor WSRC, nor any of their employees makes any warranty, expresses or implied, or assumes any legal liability or responsibility for the accuracy, completeness, or usefulness of any information, apparatus, or product, or process disclosed herein or represents that its use will not infringe privately owned rights. Reference herein to any specific commercial product, process, or service by trademark, name, manufacturer, or otherwise does not necessarily constitute or imply endorsement, recommendation, or favoring of same by the United States Government or any agency thereof. Th. 3 views and opinions of the authors expressed herein do not necessarily state or reflect those of the United States Government or any agency thereof. 


\section{A/M Area Groundwater Corrective Action Southern Sector Remediation Technology Alternatives Evaluation (U)}

June 30, 1994

B. B. Looney

M. A. Phifer

Environmental Sciences Section

Savannah River Technology Center

authentication:

$\frac{B \cdot B \cdot \text { denny }}{\text { B. B. Looney }}$

Westinghouse Savannah River Company

Savannah River Site

Aiken SC 29808

Prepared for the U. S. Department of Energy under Contract No. DE-AC09-SR 18035. 


\section{A/M Area Groundwater Corrective Action Southern Sector Remediation Technology}

Alternatives Evaluation

Table of Contents

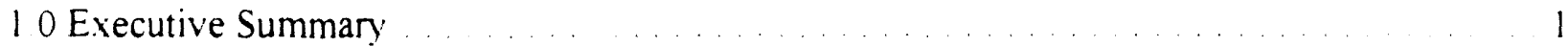

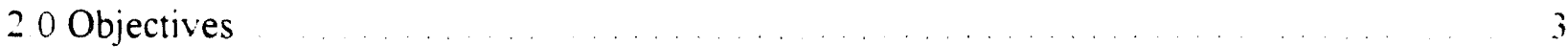

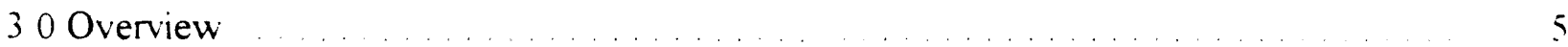

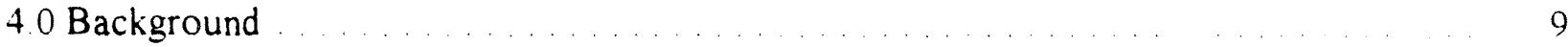

4.1 Facility Description . . . . . . . . . . . . . . . . . . . . . . . 9

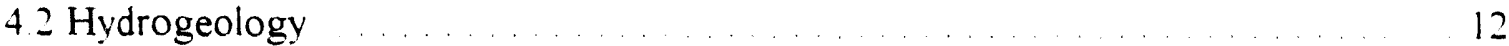

$4.3 \mathrm{~A} / \mathrm{M}$ Area Groundwater Corrective Action . . . . . . . . . . . . . 21

4.3.1 Overall Corrective Action Activities . . . . . . . . . . . . . 21

4.3.2 Specific Regulatory Issues Associated with the Southern Sector _.... 23

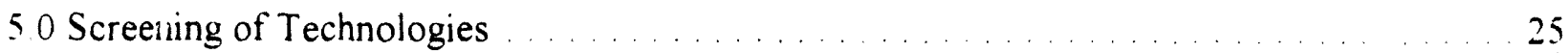

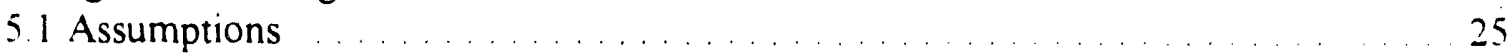

5.2 Identify Candidate Technologies and System $\ldots \ldots \ldots \ldots \ldots \ldots \ldots$

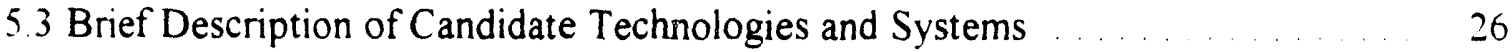

5.3.1 Natural Attenuation and Restricted Land Use . . . . . . . . . . . . . 26

5.3.2 Pump and Treat .................................... 28

5.3.3 Zero Valance Iron Enhanced Abiotic Degradation . . . . . . . . . 30

5.3.4 Airlift Recirculation Well System .................... 32

5.3.5 In Situ Air Sparging (In Situ Air Stripping) . . . . . . . . . . . . 33

536 In Situ Bioremediation .................................. 34

5.4 Identification of Most Promising Technologies and Systems _... . $\quad 36$

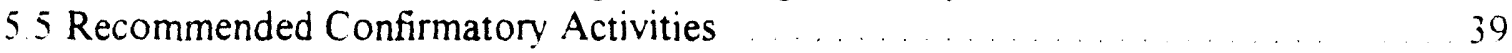

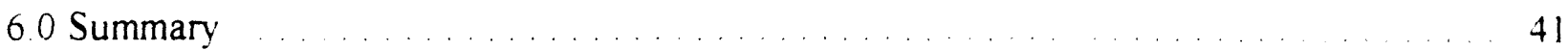

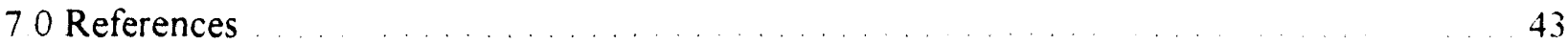




\section{A/M Area Groundwater Corrective Action Southern Sector Remediation Technology Alternatives Evaluation}

\section{1) Executive Summary}

Operations in the $\mathrm{A} / \mathrm{M}$ Area at SRS resulted in release of chlorinated solvents to the ground Release and migration of the solvents resulted in contamination of soil and groundwater TCE and PCE were first identified in samples collected from A/M Area groundwater in 1981. During the early 1980s, groundwater pump and treat was implemented to initiate contaminant removal and plume containment. By 1994, the two pump and treat systems removed and treated groundwater containing over $300,000 \mathrm{lbs}$ of solvents (about $8 \%$ of the total estimated release from the $\mathrm{M}$ Area process). These actions, permitted as a RCRA groundwater corrective action. were followed by further characterization and remediation activities to progress toward clean up goals. Additional activities have included research and development activities (vacuum extraction pilot test, in situ air stripping, bioremediation, etc.), actions to accelerate clean up of source areas (e g., vadose zone vacuum extraction and DNAPL characterization / clean up). actions to protect deeper aquifers (e.g., Northern Sector remediation and Crouch Branch Aquifer characterization), and actions to evaluate the groundwater plume and containment of plume growth (e.g., the Western Sector and Southern Sector)

Selection of appropriate action for the Southern Sector is challenging because of the large plume size and relatively low concentrations. Southern Sector clean up strategies need to be chosen to meet regulatory guidelines, compliment planned source control efforts, balance costs with benefits, and minimize environmental impacts associated with implementation. Balancing these criteria is especially important in the Southern Sector because the plume concentrations are relatively low and the groundwater is flowing toward streams onsite. In this preliminary technology evaluation, the criteria are further defined and then addressed qualitatively using a matrix. The result is a short list of the most promising systems. Any of the selected systems. carefully implemented. should meet regulatory requirements. In strategies relying on alternate concentration limits (ACLs), long term land use and land management commitments from SRS will be needed.

The technologies selected for evaluation were: natural attenuation and restricted land use. pump and treat. zero valance iron enhanced abiotic degradation. airlift recirculation wells. in situ air sparging (stripping), and in situ bioremediation. Based on the matrix. we eliminated two of the evaluated technologies from further consideration for the Southern Sector: in situ zero valance iron enhanced abiotic degradation and in situ air sparging (stripping). The plume depth and geometry are not suitable for installation and utilization of an in situ zero valence iron system Similarly, in situ air sparging (stripping) is not suited to Southern Sector conditions (e g. the depth and relatively confined nature of the core of the contaminant plume). Additionally, in situ air sparging is primarily a source area clean up (deriving much of its effectiveness from the vacuum extraction portion of the system) -- the Southern Sector does not have a vadose zone source and the vadose zone is expected to be "clean" at this distance from the sources in $\mathrm{A} / \mathrm{M}$ Area. 
Appropriate combinations of the remaining technologies appear to be the most promising approach for the Southern Sector. In particular, Natural Attenuation and Restricted Land Use appears to be an important component in any technically based corrective action for the Southern Sector Additional corrective action that targets elevated concentrations in the southern sector could be performed using pump and treat, airlift recirculation wells, or bioremediation (or a combination of these technologies). Based on the matrix, the following list summarizes the configuration of the most reasonable Southern Sector corrective action systems

Option A pump and treat portions of the Southern Sector above target concentrations combined with natural attenuation and restricted land use for the remainder of the Southern Sector plume.

Option B: airlift recirculation wells for portions of the Southern Sector above target concentrations combined with natural attenuation and restricted land use for the remainder of the Southern Sector plume

Option C: airlift recirculation wells and addition of nutrients to stimulate in situ bioremediation in the formation for portions of the Southern Sector above target concentrations combined with natural attenuation and restricted land use for the remainder of the Southern Sector plume.

These options range from baseline/traditional methods (Option A) to more innovative technologies (Options B and C). The traditional methods would be straightforward to implement, while the innovative methods have the potential to improve efficiency and reduce long term costs. Several enabling (or enhancement) technologies were identified for some of the strategies that might improve overall effectiveness. These included horizontal wells, low energy/low cost water treatment, and reinjection or wetlands enhancement to improve hydraulic control. Specific follow up evaluations and confirmatory activities were recommended to facilitate final determination of the usefulness of the enabling technologies and selection/implementation of a preferred overall strategy. For all of the options, we assumed that operation of the central treatment system (MI) and the Northern Sector treatment system (Al and A2) would continue. Further, we assumed that vadose zone remediation would be implemented near the original discharge areas. Finally, we assumed that DNAPL characterization activities will lead to appropriate expedited clean up action in the Central Area, and the Western. Southern, and Northern sectors as appropriate. These activities are important because they address future contamination potential by eliminating the sources feeding the southern sector 


\subsection{Objectives}

The following are the primary objectives of the A/M Area Groundwater Corrective Action Southern Sector Remediation Technology Alternatives Evaluation

1) integrate available site chal acierization and monitoring data, technology attributes, and regulatory/DOE guidance and policies

2) identify the most promising clean up technique(s) for the selected groundwater plume

3 ) document the evaluation process and recommend activities needed for more comprehensive analysis to finalize technology selection. 


\subsection{Overview}

Operations in the AM Area at SRS resulted in the release of chlorinated solvents, primarily trichloroethylene (TCE) and tetrachloroethylene (PCE), to the ground. Release and migration of the solvents resulted in contamination of soil and groundwater. TCE and PCE were first identified in samples collected from A/M Area groundwater in 1981. During the early 1980s. groundwater pump and treat was implemented to initiate contaminant removal and plume containment. Pilot scale groundwater pump and treat was initiated in 1983 and the full scale pump and treat system was in place and operating in 1985. By 1994, the two pump and treat systems removed and treated groundwater containing over $300,000 \mathrm{lbs}$ of solvents (about $8 \%$ of the total estimated release from the $M$ Area process). These actions, permitted under an Industrial Wastewater Treatment (IWT) permit as part of a RCRA groundwater corrective action, were followed by further characterization and remediation activities to progress toward clean up goals. Additional activities have included research and development activities (vacuum extraction pilot test, in situ air stripping, bioremediation, etc.), actions to accelerate clean up by addressing source areas (e.g., vadose zone vacuum extraction and DNAPL characterization / clean up), actions to address protection of deeper aquifers (e. 2 , northern sector remediation and Crouch Branch Aquifer characterization), and actions to evaluate the groundwater plume and containment of plume growth (e.g., the western sector and southern sector). Figure 3.1 shows a representative map of the A/M Area TCE plume in the groundwater. The highest concentrations are near the sources in the central part of $\mathrm{A} / \mathrm{M}$ Area and near the laboratory facilities. Based on DNAPL (dense nonaqueous phase liquid) characterization results (WSRC, 1990) the plume migration toward the west and southwest from the center of $\mathrm{A} / \mathrm{M}$ Area may represent DNAPL migration

The A/M Area corrective action has been structured to address logical subdomains within the overall plume. These subdomains are based on geographic position, subsurface conditions (contaminant form. media, depth, hydrogeology, etc.), and ongoing actions. The subdomains include

- Central A/M Area based on general plume capture and mass removal (the $\mathrm{Ml}$ system)

- Northern Sector based on protection of deeper zones and capture of material outside the $\mathrm{M}$ l zone of influence (the $\mathrm{Al}$ and proposed $\mathrm{A} 2$ systems).

- Vadose zone for expedited source removal (vadose zone clean up activities are planned generally within the central A/M Area)

- DNAPL characterization/remediation for expedited source removal (DNAPL activities are generally planned within the Central A/M Area -- this program may need to address portions of the Western. Southern and Northern Sectors based on additional data)

- Crouch Branch Aquifer characterization program (to determine nature and location of contamination in deep aquifer zones) -- the Crouch Branch underlies the shallow $\mathrm{A} / \mathrm{M}$ Area groundwater zones. 
- Western Sector based on material outside of Ml zone of influence and possible DNAPL migration

- Southern Sector based on capture of material outside the M1 zone of influence. flowing south toward Upper Three Runs from the Central and Western Sectors, and possible DNAPL migration

The primary source areas, and the various $\mathrm{A} / \mathrm{M}$ Area corrective action subdomains are shown in Figure 3.2. The boundaries of the various remediation sectors, the Central $\mathrm{A} / \mathrm{M}$ Area and the Northern Sector (corresponding to the generalized zones of influence for the two pump and treat systems) and the Western Sector and Southern Sector are identified on the map. The central $\mathrm{A} / \mathrm{M}$ area and the northern sector limits are based on the documented zone of capture modeling (Haselow and Koffman, 1992). The remaining subdomains are based on the shape of the groundwater plume. As described above, the other major elements of the corrective action. the vadose zone, DNAPL, and Crouch Branch Aquifer programs crosscut the geographic areas shown

Selection of appropriate action for the Southern Sector is challenging because of the large plume size and relatively low concentrations. Southern Sector clean up strategies need to be chosen to meet regulatory guidelines, complement planned source control efforts, balance costs with benefits. and minimize environmental impacts associated with implementation. Balancing these criteria is especially important in the Southern Sector because the plume concentrations are relatively low and the groundwater is flowing toward streams onsite. Planned aggressive source control actions will address, in part, the future Southern Sector plume. Thus, remediation technology selection and implementation for the Southern Sector requires care. For example. technologies that require high energy use may not be justified because the environmental impacts associated with long term energy production are greater than those associated with flow of the dilute plume edge to surface waters. In this preliminary technology evaluation, these issues are addressed qualitatively. The result is a short list of the most promising strategies. All of them, carefully implemented, should meet regulatory requirements. In cases relying on ACLs. long term land use and land management commitments from SRS will be needed. 


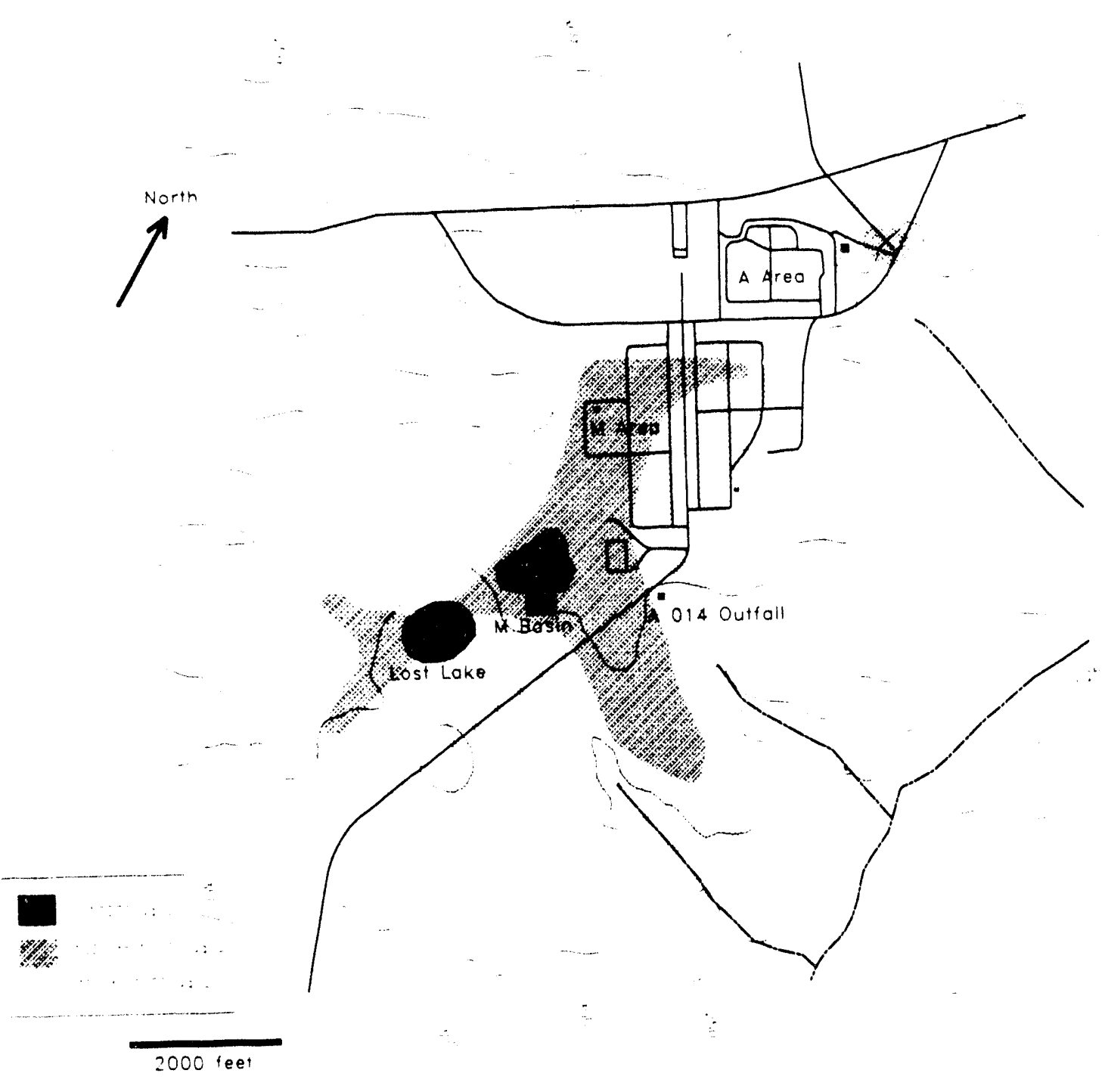

Generalized TCE plume in the southern sector of AM Area based on data collected between 1991 and 1993

Concentrations down to 100 ug/ are shown on map.

Figure 3.1. Representative Map of TCE Plume in Groundwater (Lower portion of Lost Lake Zone) Beneath $\mathbf{A} / \mathrm{M}$ Area of SRS. 


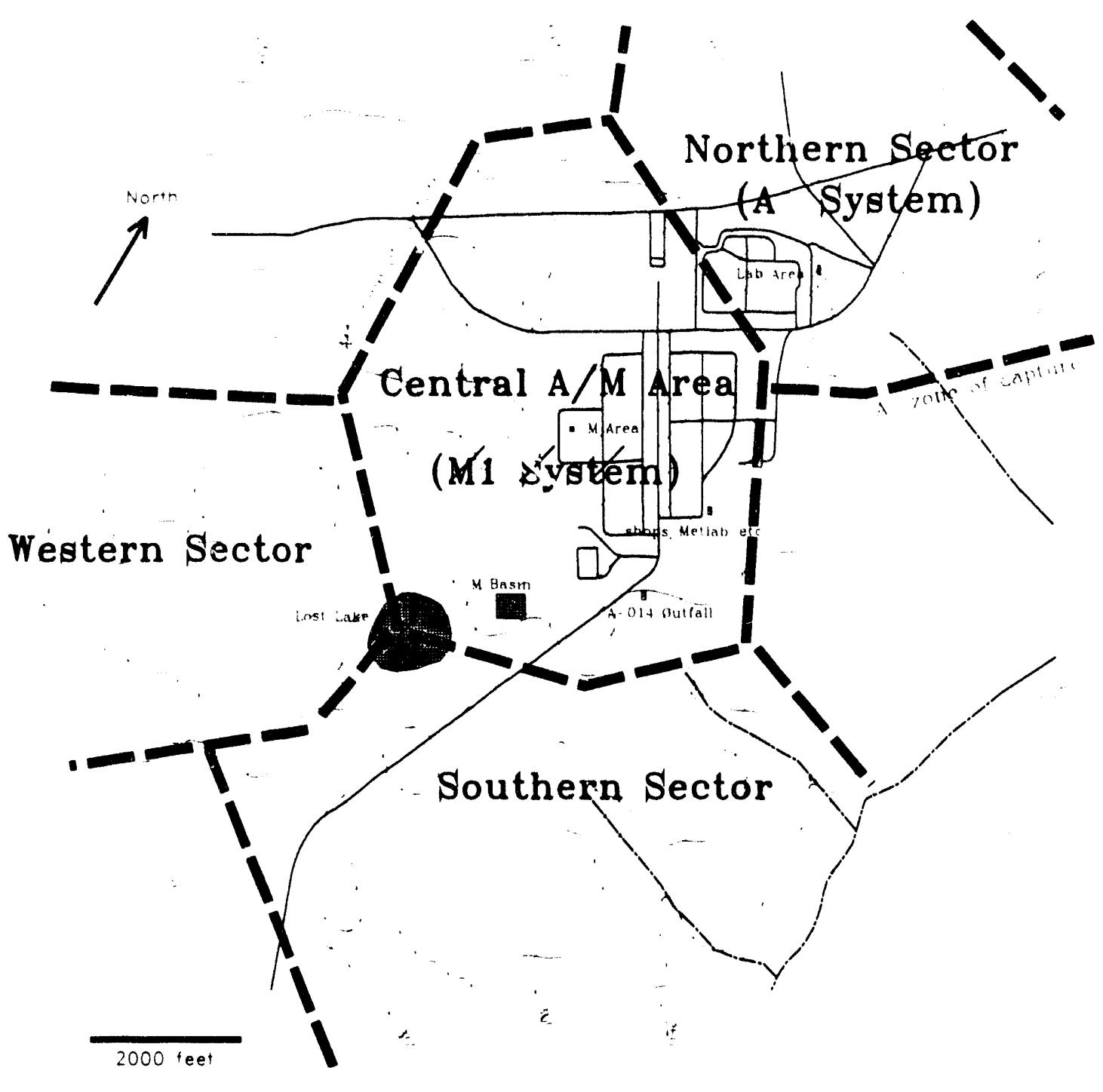

Approximate boundaries of the various geographic sectors in the $\mathrm{A} / \mathrm{M}$ Area

groundwater corrective action. Supplemental vadose zone, DNAPL, and Crouch

Branch activities are being performed as needed.

Figure 3.2. Map of $\mathbf{A} / \mathbf{M}$ Area of SRS showing source areas, and various sectors of the corrective action program. 


\subsection{Background}

\subsection{Facility Description}

The AM Area consisted of facilities for reactor fuel and target fabrication (M Area), support facilities. and the laboratories and administration facilities (A Area). As discussed below, there were several areas where cleaning solvents were used and multiple locations where solvents were released to the ground

Reactor fuel and target assemblies were fabricated in M Area. During the fabrication processes, the assemblies were degreased in vats at several stages. and cleaned at other stages with hot caustic and hot nitric acid. Based on records (see Marine and Bledsoe, 1984), solvents used in the process eventually evaporated, were collected for distillation and reuse, were collected for waste disposal, or entered process wastes. From 1952 to 1982, M Area used an estimaied 13 million lbs of chlorinated solvents. Of this total, about 3.5 million pounds were released as process waste (Table 4.1) -- about 2 million $\mathrm{lbs}$ are estimated to have been released to the $M$ Area Settling Basin and about 1.5 million Ibs are estimated to have been released to the A-014 outfall. The particular degreasing solvent used in the process changed over the years, changing from TCE, to PCE and finally to 1,1,1-trichloroethane (1,1,1-TCA). The estimated quantity and timing of the releases of the three solvents sent as process waste to the basin and outfall are shown in Figure 4.1. The timing of the releases of the various solvents, combined with chemical differences between the solvents (e.g., solubility, migration potential, etc.; Table 4.2), determine the spatial variation in solvents observed in various parts of the groundwater plume. These same factors are also important in determining the most appropriate remediation strategy for various areas within the plume. The $M$ Area Settling Basin and the A-014 Outfall represent the largest releases of solvents to the subsurface. Note, however, that several additional A/M Area sources have been identified, including facilities and outfalls at the Savannah River Laboratory (now called the Savannah River Technology Center), the $321 \mathrm{M}$ solvent storage tank, a central maintenance facility (717-A), and others. The A/M Area groundwater corrective action addresses all these sources of solvent contamination. 


\begin{tabular}{|l|c|c|c|}
\hline Table 4.1 Estimated Quantity of Degreaser Solvent Released to 1 Area Process Sewers \\
\hline Solvent & $\begin{array}{c}\text { Total Used in } \\
\text { Process }\end{array}$ & $\begin{array}{c}\text { Estimated } \\
\text { Release to } \\
\text { Settling Basin } \\
(1958-1982)\end{array}$ & $\begin{array}{c}\text { Estimated } \\
\text { Release to A- } \\
014 \text { Outfall } \\
(1952-1982)\end{array}$ \\
\hline TCE $(1952-1970)$ & 3700 & 317 & 383 \\
\hline PCE $(1962-1979)$ & 8700 & 1800 & 1000 \\
\hline 1.1 .1 -TCA (1979-1982) & 670 & 19 & 12 \\
\hline all tabulated values are in units of $10^{3}$ Ibs & & \\
\hline
\end{tabular}

\begin{tabular}{|l|c|c|c|c|}
\hline \multicolumn{2}{|l|}{ Table 4.2 Pertinent Solvent Properties } \\
\hline Solvent & $\begin{array}{c}\text { Specific } \\
\text { Density } \\
(\mathrm{g} / \mathrm{ml})\end{array}$ & $\begin{array}{c}\text { Aqueous } \\
\text { Solubility } \\
(\mathrm{mg} / \mathrm{L})\end{array}$ & $\begin{array}{c}\text { Henry's Law } \\
\text { Constant } \\
(1 \text {-atm } / \mathrm{mol})\end{array}$ & $\begin{array}{c}\text { Octanol-Water } \\
\text { Partition } \\
\text { Coefficient } \\
\text { log } \mathrm{K}_{\mathrm{ou}}\end{array}$ \\
\hline TCE & 1.46 & 1200 & 11 & 2.42 \\
\hline PCE & 1.62 & 150 & 28 & 288 \\
\hline $1,1,1$-TCA & 1.34 & 1100 & 20 & 2.48 \\
\hline
\end{tabular}

'Cohen and Mercer, 1993

'Schwarzenbach, et al., 1993 


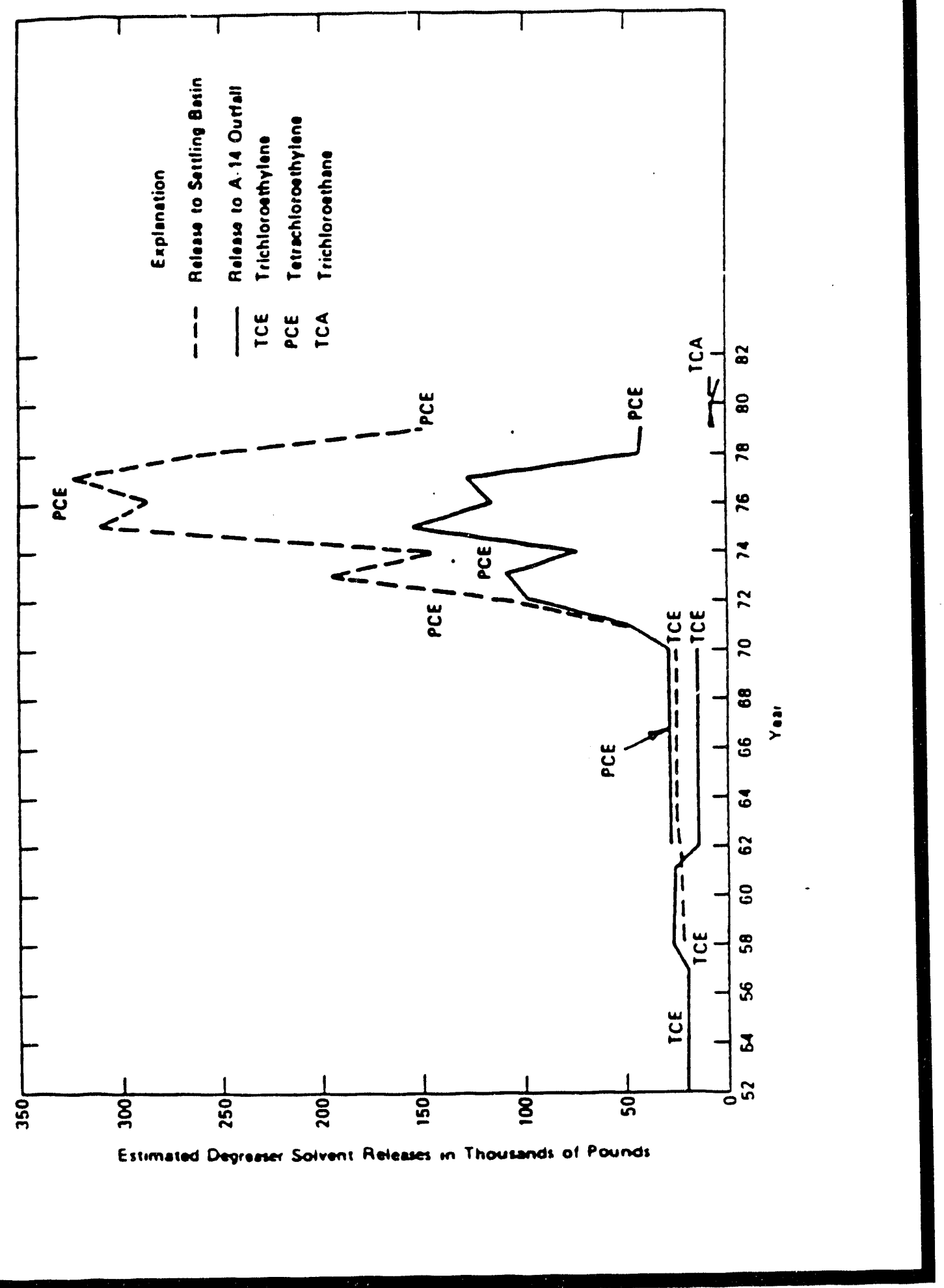

Figure 4.1. Estimated Annual Releases of Solvent to the Process Sewer (Marine and Bledsoe, 1984) 


\section{2 Hidrogeology}

Typical of the Atlantic Coastal Plain, the sediments beneath A/M Area are interbedded sands, silts. and clays. Clay rich confining, or restrictive, intervals are interspersed with more transmissive, sandier intervals. The general pattern of subsurface water flow and sequence of water bearing zones is discussed below

AM Area is located in a large interstream area between two tributaries of the Savannah River -Tims Branch and Upper Three Runs (to the South) and Hollow Creek (to the North). The primary source of water to the subsurface in this area is recharge (rainfall minus runoff and evapotranspiration) and, in the deeper aquifers, flow from offsite ("upgradient") Over most of A/M Area, recharge passes through the vadose zone into the water table zone (the M-Area aquifer zone ${ }^{l}$ ). Flow in the water table zone is both vertical (downward) and horizontal toward onsite streams. Tims Branch and its tributaries. Water reaching the deeper semiconfined zone (the Lost Lake aquifer zone, previously referred to as the Congaree Aquifer) also flows toward onsite streams, the lower reach of Tims Branch and Upper Three Runs. A leaky aquitard (the (ireen (lay confining zone) impedes water flow from the M-Area aquifer zone to the Lost Lake aquifer zone. Importantly, flow in the northernmost portion of $\mathrm{A} / \mathrm{M}$ Area (the Northern Sector) follows a different pattern. The Northern Sector of $\mathrm{A} / \mathrm{M}$ Area represents the southernmost extent of the recharge area for a deep water production aquifer (the (rouch Branch, previously referred to as the Black Creek or Upper Tuscaloosa Aquifer). Thus, in the Northern Sector, the extent of horizontal water flow in the upper zones is limited as water flow is principally downward into the deeper Crouch Branch Aquifer. Except in the Northern Sector, the aquitard (Crouch Branch Confining (init) between the Lost Lake aquifer zone and the underlying Crouch Branch Aquifer appears relatively effective in minimizing downward flow from the Lost Lake aquifer zone Figure 4.2 summarizes the hydrostratigraphy in $\mathrm{A} / \mathrm{M}$ Area.

To support technology evaluation, we can develop a simplified conceptual model of the relevant hydrology of the Southern Sector of $\mathrm{A} / \mathrm{M}$ Area based on the above description of overall $\mathrm{A} / \mathrm{M}$ Area hydrogeology. The Southern Sector occupies an area substantially downgradient from the highest concentrations in A/M Area. The Southern Sector extends from the current zone of influence of the groundwater pump and treat system to downgradient hydrologic boundary -L'pper Three Runs (see Figure 3.1). Based on the downward trajectory of the groundwater plume near the center of AM Area (with additional downward movement near the source because of the DNAPL density) the highest concentrations in the Southern Sector would be expected to be in the lower portion of the Lost Lake aquifer zone. The monitoring data shown in Figures 4.3 through 4.6 confirm this behavior. These figures show low levels of TCE in the M Area aquifer zone, intermediate levels of TCE in the upper portion of the Lost Lake aquifer zone

${ }^{1}$ Each water bearing zone is described in the text followed by a parenthetical list of names that have been applied to that zone. The most recent nomenclature (Lewis and Aadland, 1992) is italicized and will be used throughout this report 
and in the middle sand of the Crouch Branch Confining Unit Figure 4.5 shows significantly higher levels of TCE in the lower portion of the Lost Lake aquifer zone Contamination in the Southern Sector is primarily TCE because of its early use and because its solubility and mobility are higher than PCE (PCE concentrations are 10 to 100 times lower than TCE in the southern sector). A simplified cross section of the lithology specific to the southern sector is shown in Figure 4.7 and hydrologic parameters important to technology evaluation are summarized in Table 4.3 


\begin{tabular}{|c|c|c|}
\hline $\begin{array}{l}\text { Geologic } \\
\text { Conditions } \\
\text { ( see figure } 40 \text { ) }\end{array}$ & $\begin{array}{l}\text { Interbedded sand and clays creating significant } \\
\text { heterogeneity }\end{array}$ & $\begin{array}{l}\text { Lewis and } \\
\text { Aadland. } \\
1992\end{array}$ \\
\hline $\begin{array}{l}\text { Hydrologic } \\
\text { Conditions } \\
\text { (see figure 42) }\end{array}$ & $\begin{array}{l}\text {-M Area aquifer zone } \\
\text { •vertical (downward) flow predominates in central } \\
\text { A/M Area } \\
\text { •horizontal flow toward streams near periphery of } \\
\text { A/M Area ( south and east) } \\
\text {-Lost Lake aquifer zone. } \\
\text { •vertical flow to lower portion of Lost Lake } \\
\text { aquifer zone in central A M Area } \\
\text {-horizontal flow to lower reach of Tims Branch } \\
\text { and Upper Three Runs in Southern Sector } \\
\text { •k } \approx 10^{-2} \mathrm{~cm} / \mathrm{s} \\
\text {-Crouch Branch Corfining Unit } \\
\text { •relatively effective in minimizing downward flow } \\
\text { from Lost Lake aquifer zone in central AM Area } \\
\text { and Southern Sector }\end{array}$ & $\begin{array}{l}\text { Lewis and } \\
\text { Aadland. } \\
1992 . \\
\text { Hiergesell. } \\
1993\end{array}$ \\
\hline $\begin{array}{l}\text { Contaminant } \\
\text { Plume }\end{array}$ & 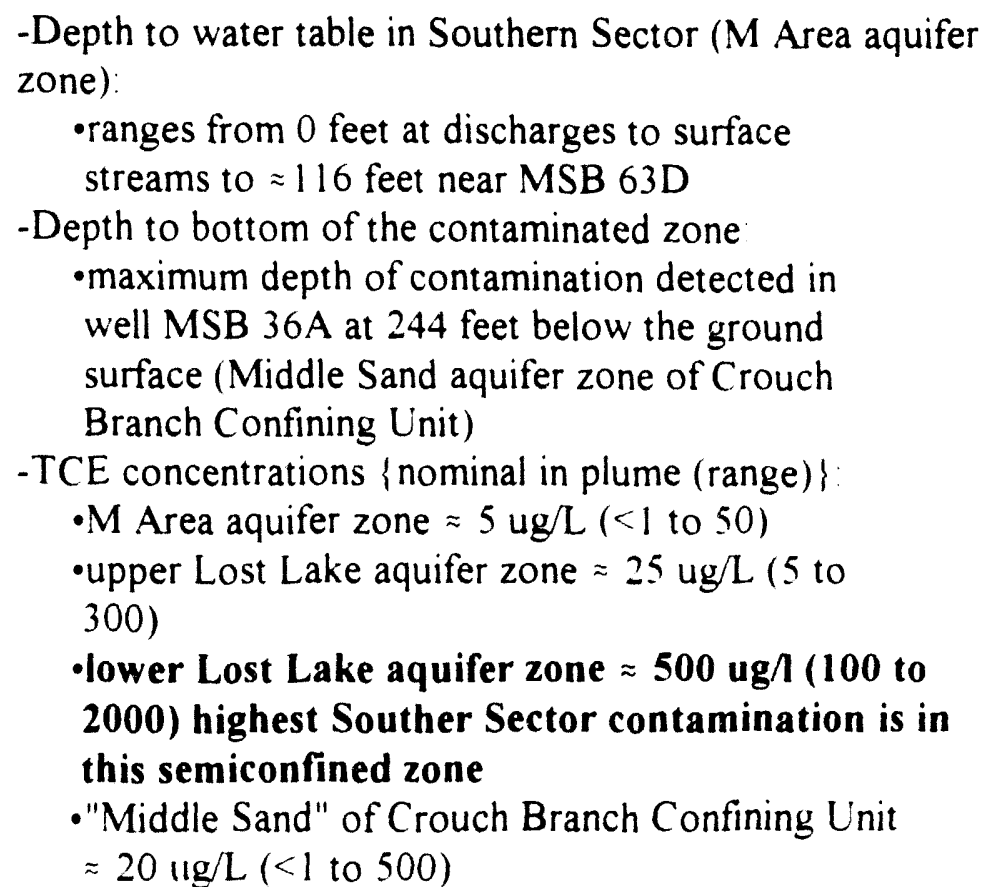 & $\begin{array}{l}\text { Lewis and } \\
\text { Aadland. } \\
1992 \text {. } \\
\text { ESH-EMS- } \\
930098 \text {. } \\
\text { ESH-EMS- } \\
930262 \text {. }\end{array}$ \\
\hline
\end{tabular}




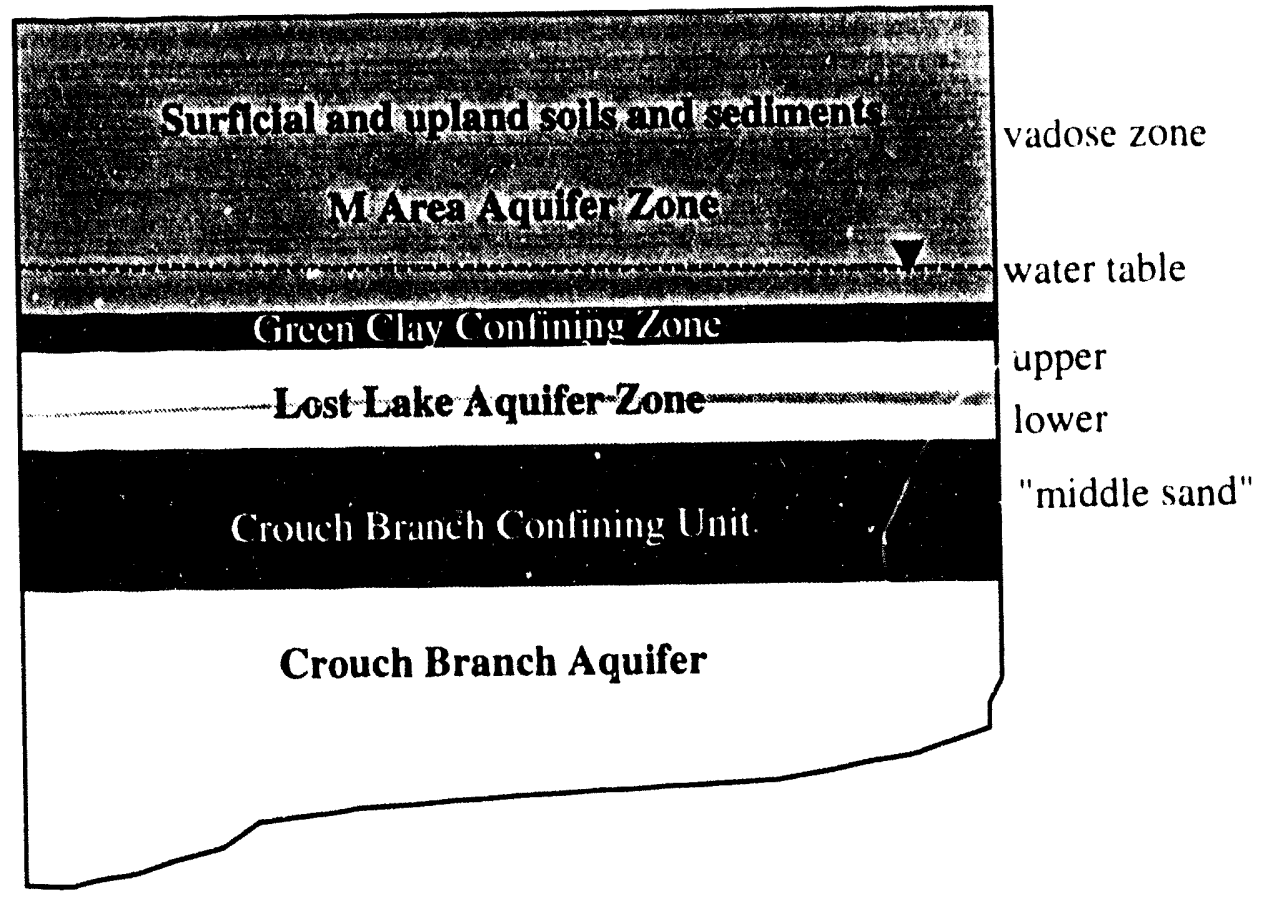

Figure 4.2. Simplified Hydrostratigraphy in the A/M Area of SRS 


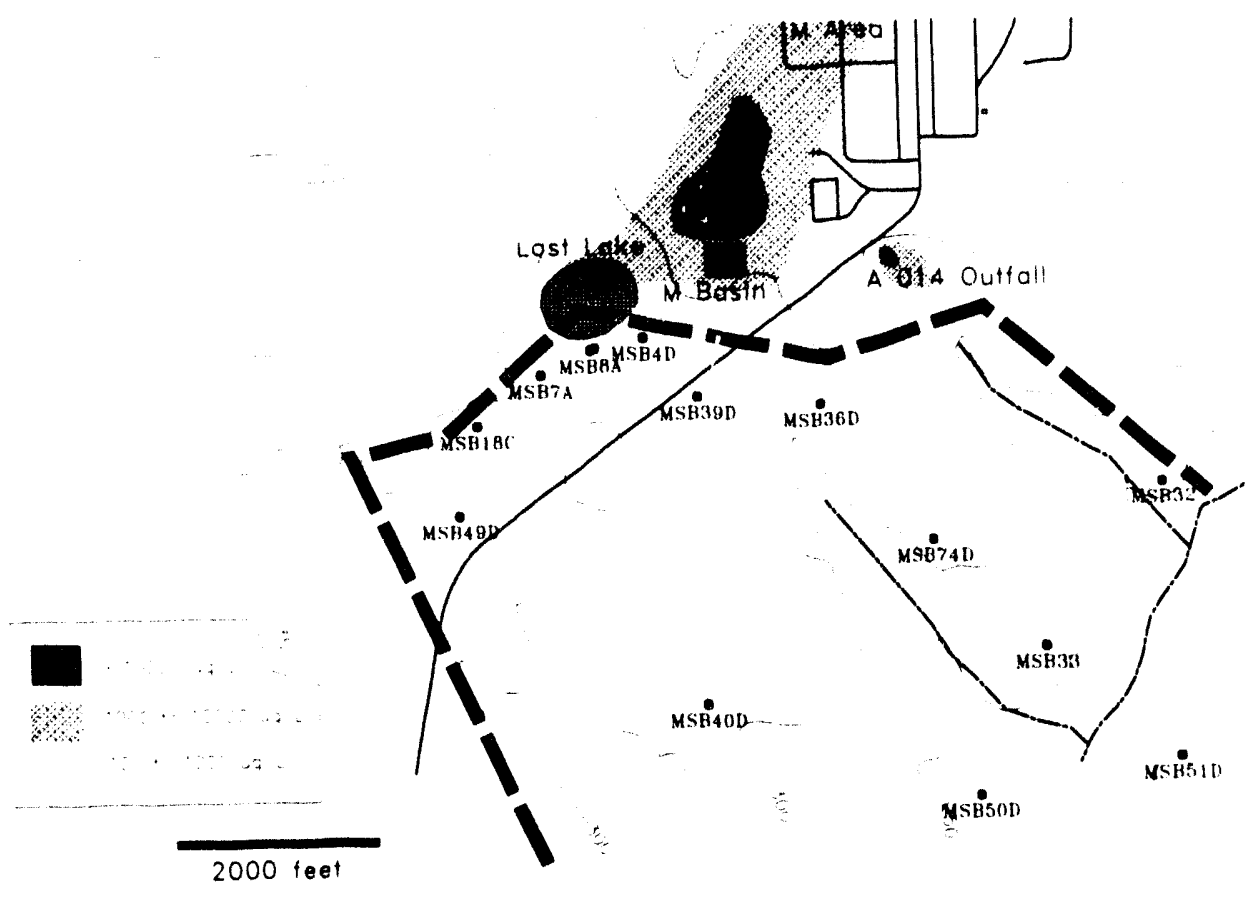

Generalized TCE phume in the southern sector of AM Area based on data collected between 1991 and 1993

Concentrations down to 100 ug/ are shown on map

Dashed tine indicates approximate boundary of eouthern sector. Wells monitoring this zone in the southern sector are shown for reference.

Figure 4.3. Isoconcentration Map for TCE in the M Area Aquifer (water table) zone in the southern sector of $\mathbf{A} / \mathbf{M}$ Area 


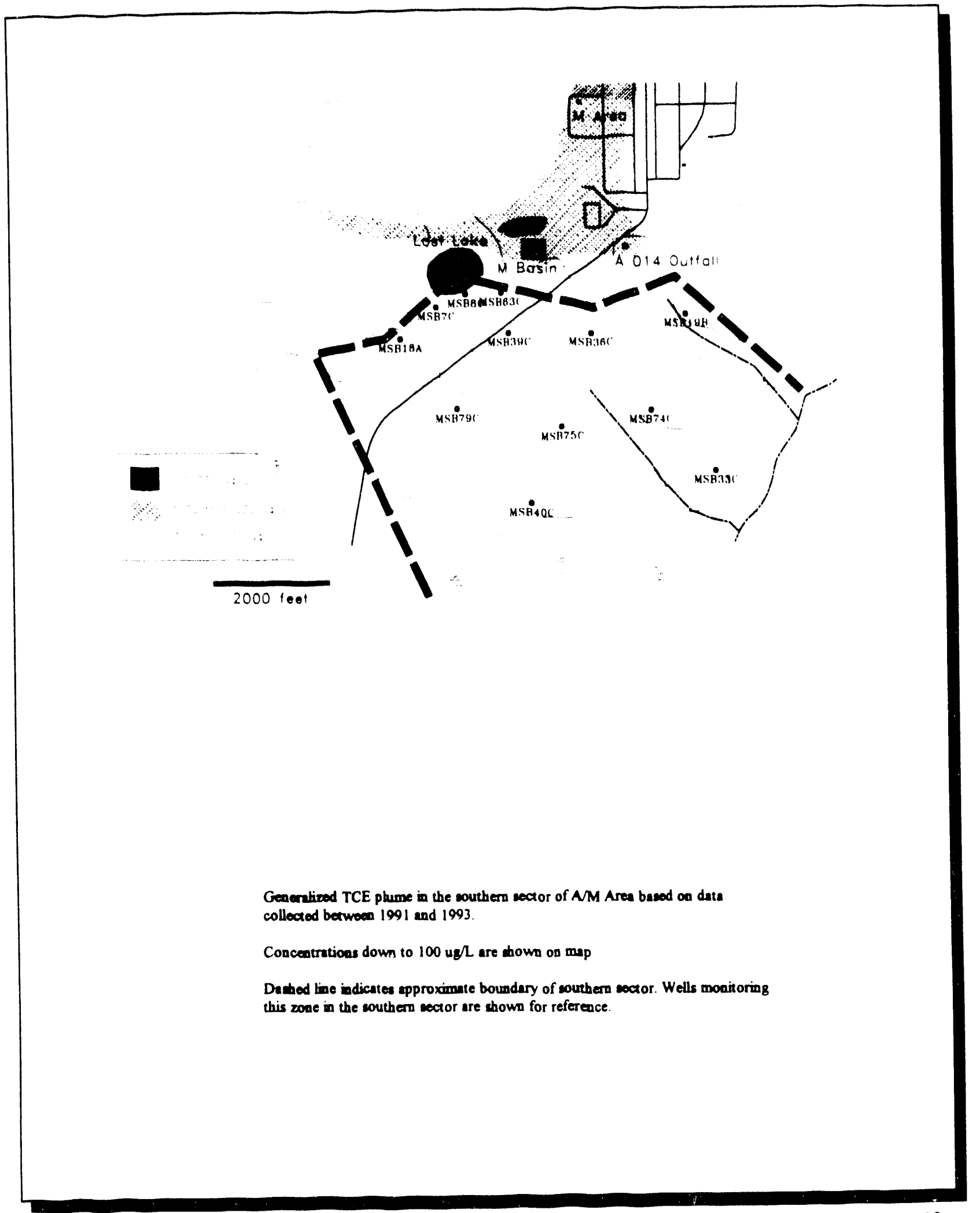

Figure 4.4. Isoconcentration Map for TCE in the Upper Portion of the Lost Lake Aquifer zone in the southern sector of $\mathrm{A} / \mathrm{M}$ Area 


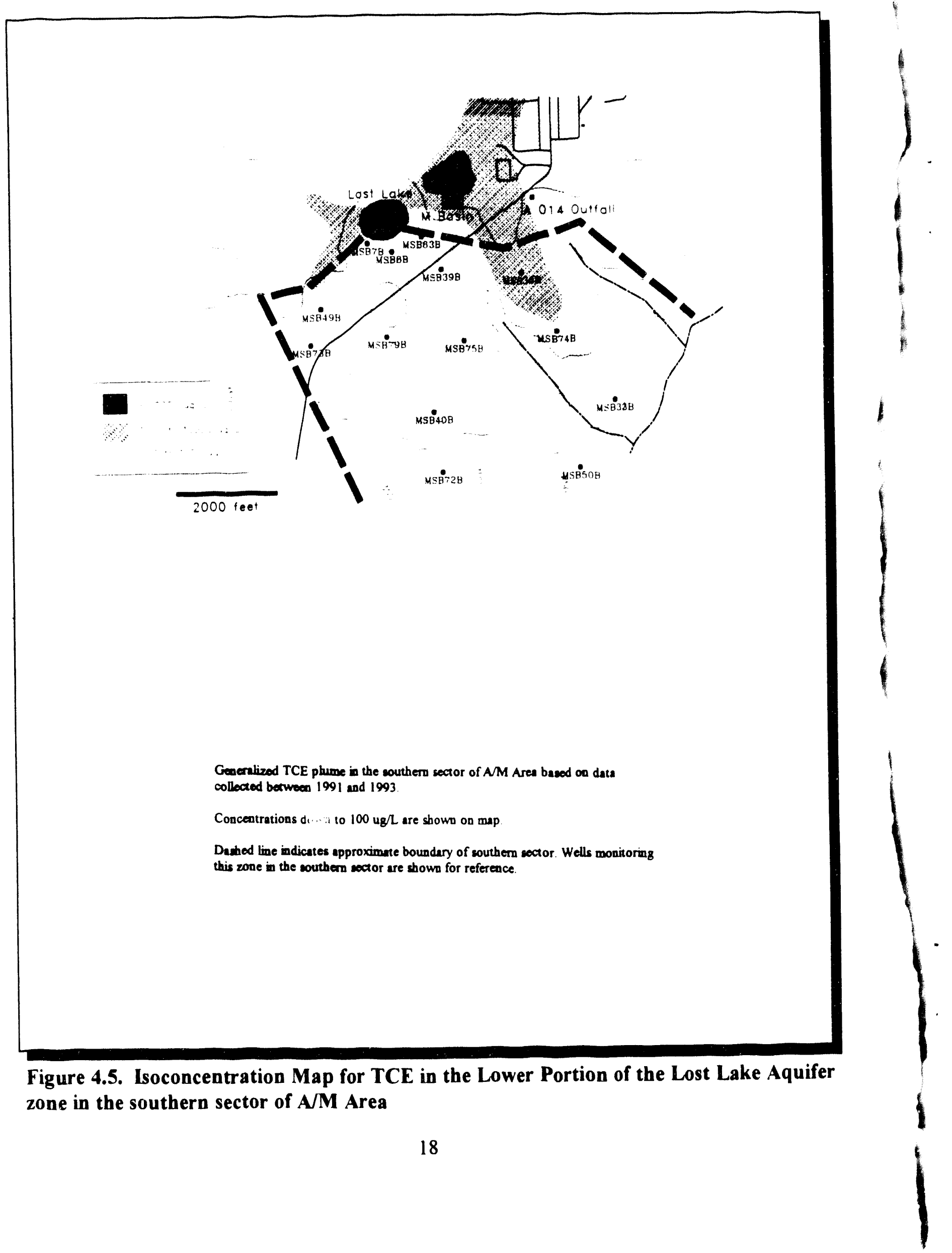




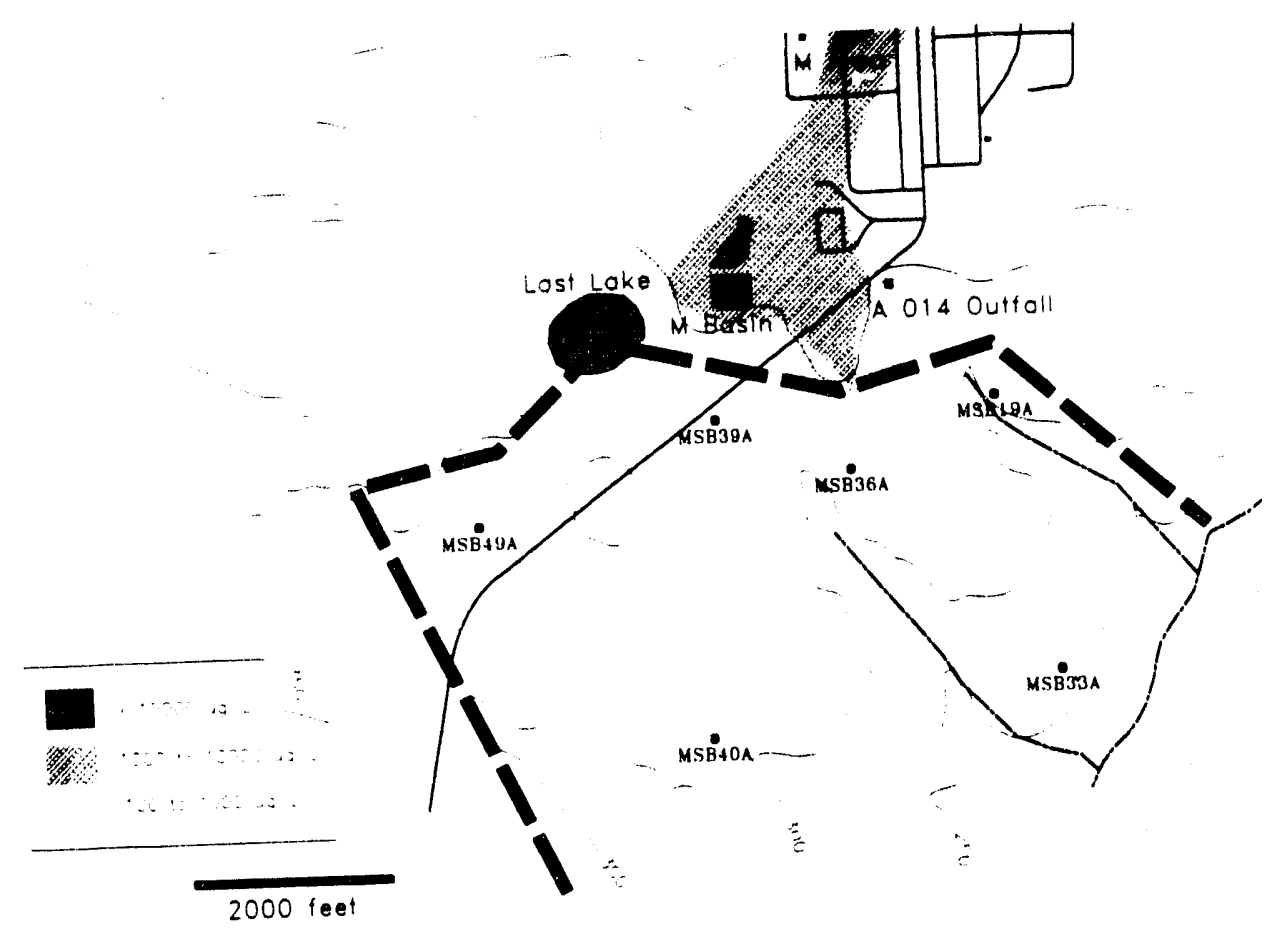

Generalized TCE phume in the sourbern sector of AM Area based on data collected between 1991 and 1993

Concentrations down to 100 ug $\mathrm{L}$ are shown on map.

Dashed line indicates approximnte boundary of southem sector. Wells movitoring this zone in the southern sector are shown for reference.

Figure 4.6. Isoconcentration Map for TCE in the middle sand of the Crouch Branch Confining zone in the southern sector of $\mathbf{A} / \mathbf{M}$ Area 


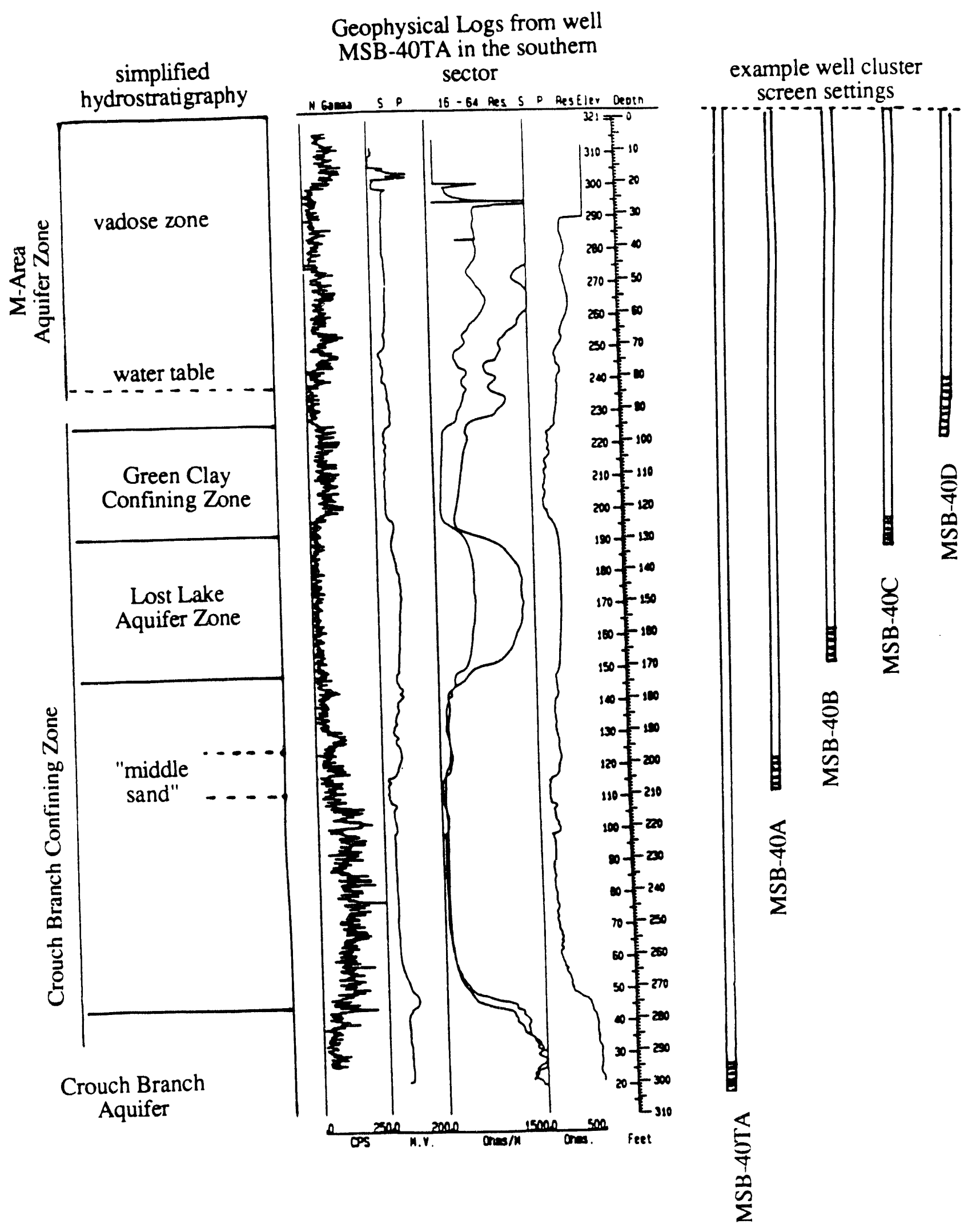

Figure 4.7. Nominal Lithology in the Southern Sector of $\mathbf{A} / \mathbf{M}$ Area. 


\section{3 A M Area Groundwater Corrective Action}

\subsection{Overall Corrective Action Activities}

From the 1950 s to 1985, M Area process wastes were discharged to the M Area Settling Basin and the A-014 Outfall. The settling basin was an eight million gallon capacity, unlined surface impoundment designed to settle and contain metal hydroxide precipitates discharged from the tuels and target fabrication processes. The $\mathrm{M}$ Area waste stream contained metals (nickel, aluminum, uranium, lead). acids, caustics, and solvents associated with the aluminum-forming and electroplating processes. Under the Resource Conservation and Recovery Act (RCRA) Hazardous Waste Listings promulgated in 1980, the waste stream was classified as F006 electroplating waste.

SRS submitted a RCRA Part A permit application in 1980, putting the M Area HWMF under interim status. Interim status procedures included regular facility inspections, personnel training, and various reports, including groundwater monitoring data. In September 1984, SRS submitted a closure plan for the HWMF This plan was approved by the South Carolina Department of Health and Environmental Control (SCDHEC) in July 1987. Closure of the settling basin began in April 1988. following approval of the related National Pollutant Discharge Elimination System (NPDES) and wastewater construction permits. The settling basin was closed by dewatering and stabilizing the sludge at the basin bottom. The basin was then backfilled with any surrounding soils contaminated by basin operation and covered by a cap containing a synthetic liner and a clay barrier to limit water infiltration through the stabilized waste. Closure of the basin was completed in 1990 and final approval of the work was received from SCDHEC in 1991 .

Groundwater clean up was initiated in February 1983 through operation of an experimental pump and treat system. In February 1985, SRS submitted a RCRA Part B permit application addressing post closure maintenance of the basin, and groundwater monitoring and corrective action. Importantly, the permit application committed SRS to remediate all solvent contaminated water in $\mathrm{A} / \mathrm{M}$ Area, and to evaluate svstem effectiveness and make appropriate modifications to improve system performance. To meet its commitments, SRS initiated operation of a full scale ( 500 to $600 \mathrm{gpm}$ ) pump and treat system (known as the Ml system) in November of 1985. This RCRA Pa.t B permit was approved in September 1987. At that time. SRS agreed to submit a 5 year renewal of the permit to designate the proposed modifications The renewal permit, known as the "1992 RCRA Part B Renewal Application" was submitted in 1992

Additionally, SRS has pursued a range of research and development activities, expanded site characterization activities, and projects to improve the effectiveness of the groundwater corrective action. Areas outside the zone of influence of the Ml system have been identified and appropriate corrective actions are being identified. For example, shallow groundwater near the northern border of $A / M$ Area is outside the influence of the $M 1$ system. As discussed above. clean up of the shallow zones in this Northern Sector is important because the groundwater in 
this area flows downward into the Crouch Branch Aquifer. To rapidly address the contamination in this important area, a small pump and treat system (approximately $70 \mathrm{gpm}$ ) was constructed and began operation in 1992. Additional recovery wells and treatment capacity are currently. being added to the northern sector system (A2 system). By 1994, the groundwater pump and treat systems removed and treated groundwater containing over $300.000 \mathrm{lbs}$ of solvents (about $8^{\circ} \circ$ of the total estimated release from the M Area process). Corrective action alternatives for the Southern Sector (which is also outside the influence of the Ml system) are currently being evaluated. Characterization and corrective action development activities are also underway for the Crouch Branch Aquifer and the Western Sector.

Related compliance and research and development activities have included

-Full scale testing of soil vapor extraction (SVE), a process to remove solvent from the soil beneath old sources before it enters the groundwater. A detailed study near the known M Area sources was completed and several SVE systems have been designed and are scheduled for start up as part of the RCRA Part B corrective action in 1994 -Research and development activities demonstrating new clean up processes and the usefulness of horizontal drilling in remediation systems have been completed. In the course of the tests, seven horizontal wells were completed, documenting the applicability of drilling methods from different industries (e.g., oilfield, utility, river crossing). Using the wells and test areas, the following technologies were tested: in situ air sparging using horizontal wells, in situ methanotrophic bioremediation, radio frequency heating and six phase resistive heating of vadose zone clays to enhance SVE, innovative offgas treatment methods (photodegradation, advanced oxidation methods, etc.), and innovative characterization and monitoring methods (crosshole geophysical tomography, real time VOC sensors, digital imaging of environmental data, etc.)

-Evaluation of the nature and extent of residual solvent in the soil and groundwater in A/M Area. TCE and PCE have a low water solubility. As a result, near the release point. they tend to accumulate as residual solvent. This residual solvent is known as nonaqueous phase liquid (NAPL). The chlorinated solvents are denser than water so they are referred to as dense NAPL (DNAPL). The residual DNAPL is present both above the water table (in the vadose zone) and below the water table. While this material migrates relatively slowly, it serves as a long term "source" to more rapidly flowing groundwater As groundwater moves past the source zone it is contaminated by contact with the residual solvent. Continued migration of this water as it flows toward hydrologic boundaries such as surface streams, results in a relatively large contaminated plume Careful characterization and targeted remediation of the DNAPL phase are important activities that eliminate the future long term contamination source. 


\subsection{Specific Regulatory Issues Associated with the Southern Sector}

The renewal RCRA permit application, known as the "1992 RCRA Part B Renewal Application" was sut mitted in 1992. This renewal permit application included proposed actions specific to the Southern Sector remediation. The proposed actions for the Southern Sector included

-Additional geohydrologic and plume characterization and subsequent model updates -Installation of groundwater recovery wells to withdrawal and establish hydraulic control over contaminated groundwater containing greater than approximately $500 \mathrm{ppb}$ TCE -Design of a remediation system to treat contaminated groundwater containing greater than approximately $500 \mathrm{ppb}$ TCE -Performance of an exposure assessment to determine the groundwater contamination level to which hydraulic control should be established and maintained -The exposure assessment would be used to determine the need to construct a remediation system

A Notice of Deficiency (NOD) dated May 27, 1994, from SCDHEC was received by WSRC The NOD essentially stated that remediation of the Southern Sector contamination plume should proceed in two phases. Phase I should proceed immediately to design, construct, and operate a system to capture and treat the portions of the plume with greater than approximately $500 \mathrm{ppb}$ TCE. Phase II should be developed to address the rest of the plume through further remediation and/or submittal of an ACL demonstration.

A revised Part B permit application has been prepared that proposes the following

-Additional geohydrologic and plume characterization and subsequent model updates -Phase I remediation of hot spot contamination in the Southern Sector -An evaluation of alternative technologies for remediation for use in the Phase I remediation.

-Phase II remediation and/or submittal of an ACL demonstration. 


\subsection{Screening of Technologies}

\subsection{Assumpuons}

Technology identification and evaluation was based on 1) the site description summarized above. 2) sufficient technology performance and applicability documentation in the literature (i. e. regulatory recognition of existing or best available technologies, or completion of actual field demonstration for innovative technologies), and 3 ) continued progress in the related elements of the overall $\mathrm{A} / \mathrm{M}$ Area groundwater corrective action. Thus, we assumed that operation of the central treatment system (MI) and the Northern Sector treatment system (Al and A2) would continue. We assumed that vadose zone remediation would be implemented near the original discharge areas. Finally, we assumed that DNAPL characterization activities will lead to appropriate expedited clean up action in the Central Area, and the Western. Southern. and Northern Sectors as appropriate. The site conditions and these related actions provide the appropriate context for the technology screening

\subsection{Identiff. ('andidate Technologies and System}

An array of technologies and supporting systems were identified for evaluation. To determine the array of appropriate candidate technologies, we reviewed information summarized in the following sources:

-Mixed Waste Management Facility Alternate Corrective Action Plan: Groundwater Remediation Technology Selection (Looney and Haselow, 1993)

-A Summary of Literature on Subsurface DNAPL Remediation (Bramblett. et al, 1993)

-Southern Sector Groundwater Remediation, Air Abatement Alternatives (Rehder, 1992)

In a previous study for similar contaminants, we reviewed the following

$$
\begin{aligned}
& \text {-EPA Vendor Information System for Innovative Treatment Technologies (VISITT) Data } \\
& \text { Base. } \\
& \text {-EPA Alternate Treatment Technology Information Center (ATTIC) Data Base. } \\
& \text {-DOE Office of Technology Development Technology Profiles (PROTECH) Data Base }
\end{aligned}
$$

Additionally, the annual Superfund Innovative Technology Evaluation Program Technology Profiles. reports from the integrated VOC remediation technology demonstrations in M Area. technical literature, and articles in environmental newsletters were utilized

The technologies selected include natural attenuation and restricted land use. pump and treat. zero valance iron enhanced abiotic degradation, airlift recirculation wells, in situ air sparging (stripping). and in situ bioremediation 


\subsection{Brief Description of ( andidate Technologies and Sistems}

This section briefly describes potential remedial technologies which are currently most applicable to the A/M Area Southern Sector Plume. The overview for each technology includes a technology description, applications and limitations, and specific issues related to applicability is the Southern Sector plume. Enabling technologies and optional system components to enhance the efficiency of each candidate system are highlighted in the technology description section. For example, horizontal wells may improve the performance of several of these technologies since the plume in the Southern Sector is in a relatively thin, but laterally extensive. zone. Other adjunct technologies include reinjection of water to retard further plume spread. and innovative water and offgas treatment systems.

\section{Natural Attenuation and Restricted Land Use Technology Descripition}

The natural attenuation and restricted land use alternative is based upon attenuation of contaminant concentrations to acceptable levels at potential surface exposure locations combined with groundwater use restrictions over the affected area. Natural attenuation is achieved through dispersion and/or natural degradation (typically biodegradation) of the contaminants during groundwater transport to a potential receptor location, such that the concentrations at receptor locations are below levels of concern. Restricted land use is established over land areas associated with the on-site contaminated groundwater such that human access and consumptive use is prohibited. Potential receptors with such restricted land use would include off-site surface and groundwater users, on-site ecological receptors, on-site workers, and intruders at potential surface exposure locations.

\section{Technology Application and Limitations}

Application of this technology relies upon approval of an Alternate Concentration Limit (ACL. see South Carolina Hazardous Waste Management Regulation R.61-79.264.94), which is based upon establishment of restricted land use which prohibits consumptive use of on-site contaminated groundwater and documentation of acceptable concentrations at potential surface exposure locations. Acceptance of the concept of restrictive land use and evaluation of only potential surface exposure locations by the regulators and public would be required. Appropriate modeling would be required to demonstrate that concentrations below concern would exist at potential receptor locations. Long term monitoring would also be required to prove that the concentrations at potential receptor locations remain below concern. Under this option the contaminant plume would be allowed to flow toward the natural downgradient streams onsite -Tims Branch and Upper Three Runs. If it was determined at a later date that the natural attenuation and restricted land use were no longer aprropriate, treatment of the expanded dimensions of the plume would be required. 
This approach is a passive, naturally occurring, in situ application similar to a remedial option recently approved by EPA for contaminated groundwater at the Florida Steel Superfund Site At this site the record of decision (ROD) provides for the extraction and blending of contaminated groundwater with clean water to produce a blended water with contaminant levels below the maximum contaminant level (MCL). This blended water will be discharged through a spray field (Hazardous Waste News. 1994)

\section{Technology Applicability to Southern Sector Plume}

The primary contaminants associated with the Southern Sector plume are trichloroethylene (TCE) and tetrachloroethylene (PCE) (Lewis and Aadland. 1992). The sources of these contaminants are the A-14 outfall, the M-Area Settling Basin, and Lost Lake. The plume for the most part is relatively dilute and covers a large area. TCE and PCE have maximum Southern Sector groundwater concentrations of 1800 and $170 \mathrm{ppb}$ respectively (not including the area immediately adjacent to the A-14 outfall which is included in the current pump and treat system and proposed vadose zone treatment system). The highest level of contamination is in the lower Lost Lake aquifer zone with lower levels of contamination measured in the upper Lost Lake aquifer zone. the $M$ Area aquifer zone and the Middle Sand aquifer zone of the Crouch Branch Confining Unit. In the Southern Sector, as the plume approaches the downgradient streams. the flow path will shift to a horizontal and upward trajectory. The leading edge of the plume may be currently outcropping into Tims Branch. However with future transport, the bulk of the plume should outcrop into Upper Three Runs There is minimal potential for migration into the Crouch Branch Aquifer in the Southern Sector, due to the thickening of the clays in the Crouch Branch Confining Unit in this area and the impact of the draining streams in reducing heads in the Lost Lake aquifer zone Under natural conditions, chlorinated solvents such as TCE and PCE degrade slowly (reliable biodegradation requires addition of other carbon and nutrient sources such as methane), therefore. the primary mechanisms associated with natural attenuation are dispersion/dilution combined with the implementation of the other parts of the $A / M$ corrective action (the M1 system, source remediation of the vadose zone and DNAPLs. etc.) These related activities should preclude the future arrival of higher concentrations

In future migration and outcropping scenarios, significant dilution is expected prior to use by a potential off-site human receptor. The receptors with the highest potential for future exposure include on-site ecological receptors. on-site workers, and intruders at the Upper Three Runs groundwater seeps. This option appears appropriate and technically viable for the Southern Sector Appropriate modelling would be required to demonstrate technical viability by demonstrating that future concentrations would remain below levels of concern at potential receptor locations However it requires approval of an Alternate Concentration Limit (ACL) and acceptance of the concept of limited land use by the regulators and public 


\section{Pump and Treat}

\section{Technology Description}

Pump and treat systems operate by removal of the contaminated groundwater, usually by wells, for treatment at the surface The surface treatment can consist of any of a number of chemical. biological, or physical methods or a combination Potential surface treatment technologies for chlorinated volatile organic compounds (CVOCs) at low concentration $(<500 \mathrm{ppb})$ in water include air stripping with offgas treatment (if required), zero valance iron enhanced abiotic degradation, advanced oxidation processes in the water (e.g. UV with ozone or peroxide, electron beam, or similar systems), spray irrigation, or bioremediation (Looney and Haselow. 1993) Because of the low concentrations, selection of a treatment technology for contaminated water from a pump and treat system of this type must be carefully selected to avoid unreasonable energy costs associated with operation

A second enhancement technology that should be considered for a southern sector pump and treat system is horizontal wells. Depending on the specific remediation goals, these wells may enable more efficient extraction of groundwater

Pump and treat systems typically produce, at a minimum, a treated aqueous effl sent that must be disposed. Typically the aqueous effluent is either discharged through an NPDES permitted outfall or reinjected into the groundwater in which case an Underground Injection Control (UIC) permit would be required. Reinjection can be utilized as a means to establish hydraulic control of the plume. Depending upon the treatment technology selected (ie air stripping or spray irrigation), an air discharge may also be produced which would require an Air Permit/Waiver An alternative for handling the treated water in the southern sector would be wetlands enhancement In this case a topographic low with hydric, or near hydric, soils would be identified. The treated water from the pump and treat operation could be added to the area to enhance the size/quality of the wetland. As with reinjection, this option would require careful follow up evaluation to justify final selection assure proper implementation Wetland enhancement may require an NPDES permit and interactions with the U S Army Corps of Engineers, the Environmental Protection Agency, and others

\section{Technology Application and Limitations}

Water extraction in pump and treat systems can be optimized to meet multiple objectives. Wells at the edge of the plume limit plume spread and provide hydraulic control, while wells installed near the source remove high quantities of contaminant. One well documented disadvantage of pump and treat systems is the slow rate that they reduce high plume concentrations down to the drinking water standards. This slow concentration reduction, or long tail. results from residual inputs from the vadose zone. mass transfer limitations. and heterogeneities in the subsurface system. In the case of CVOCs, the presence of non aqueous phase liquid (NAPL) provides a long term source to the groundwater (stabilizing concentrations until the NAPL is dissolved) (Looney and Haselow, 1993) Prior to implementation of this technology, groundwater pump 
tests would be required to determine the withdrawal rates and zone of influence associated with recovery wells Related $\mathbf{A} / \mathbf{M}$ Area Corrective Action activities are being performed to address the presence of DNAPL and to remediate the highest concentration areas (the $\mathrm{MI}$ and $\mathrm{Al}$ svistems)

\section{Technology Applicability to Southern Sector Plume}

Pump and treat technology can be applied to the Southern Sector However, due to the large area and multiple flow directions (Lewis and Aadland. 1992) of the Southern Sector plume. recovery wells would have to be placed throughout the plume While the principal extraction would be from the lower Lost Lake aquifer zone, the system might require recovery wells screened in multiple aquifers to provide necessary control of plume spread (based on corrective action objectives). Using standard approaches, a significant groundwater withdrawal rate and treatment of large volumes of groundwater with low concentrations of contaminants might be required These problems might be addressed by careful utilization of horizontal wells and reinjection

Horizontal wells may improve efficiency by providing 1) the ability to target the depth of highest concentration to maximize contaminant recovery while minimizing water extraction, 2) a greater screen length than would be possible with vertical wells in the lower Lost Lake aquifer zone (a relatively thin but laterally extensive zone), and 3) simplification of surface engineering (through reduction of the amount of surface piping and power needs to multiple vertical well locations. etc ) Installation of horizontal wells at these depths would require application of relatively expensive modified oilfield or modified river crossing methods Thus, a combination of horizontal and vertical wells as needed to address groundwater exceeding target levels in the various zones may provide the inost efficient pump and treat system

Disposition of the treated water in the Southern Sector should be a factor in final technology selection activities. Existing NPDES outfalls are not conveniently located for southern sector discharges (potentially leading to high cost, high maintenance, piping) Other options for treated water disposition (reinjection or wetlands enhancement). as discussed below, require careful further evaluation

The use of reinjection as a means to establish hydraulic control in the Southern Sector may provide options for reduced plume expansion rate ("hydraulic control). In this case, injection of treated water into the principal contaminated zone. well downgradient of the target concentrations, would reduce plume expansion. Treated water from a Southern Sector pump and treat system. or other sources of clean water might be used Reinjection should be carefully evaluated and instituted only after resolution of several specific issues. 1) documentation of substantial long term reduction in plume expansion, 2) documentation that reinjection will not result in undesirable increases in vertical migration, and 3 ) determination that the spread of low concentration contaminants in the vicinity of the injection will not result in enlargement of future clean up (pump and treat) actions 
In wetland enhancement. treated water from the pump and treat system could be added to a low Iving area to enhance the size/quality of the wetland Based on preliminary surveys, the southern sector has suitable habitats for this approach Evaluation of this option will require documentation that the area will be enhanced during operation, and that stopping operation at a future date will not have catastrophic ecosystem impacts (i e develop shut down strategies) The regulatory requirements and commitments related to the option require careful evaluation. especially federal wetlands regulations Balancing these concerns, however, is the positive nature of this "green approach" to clean up Properly implemented, with full involvement of appropriate public organizations (e.g. Nature Conservancy), this option would generate a unique positive environmental impact from operation of the groundwater corrective action

\section{Zero Valance Iron Enhanced Abiotic Degradation}

\section{Technology Description}

Zero valance iron enhanced abiotic degradation of chlorinated volatile organic compounds (CVOCs), as developed by the University of Waterloo, is essentially a reductive dechlorination process. The zero valance iron is oxidized which supplies electrons for the reduction of CVOCs which results in the replacement of chlorine atoms with hydrogen atoms on the organic molecule This results in final degradation products such as ethene, ethane, and methane. if the dechlorination process is complete. (Orth, 1992; O'Hannesin and Gillham, 1992; O'Hannesin. 1993. Gillham, O'Hannesin, and Orth, 1993). A potencial enhancement to this technology has been identified by the U.S. Environmental Protection Agency (EPA) Environmental Research Laboratory in Athens, Georgia EPA has noted that the addition of pyrite $\left(\mathrm{FeS}_{2}\right)$ and possibly sulfur to the iron will maintain the $\mathrm{pH}$ in the optimum range for the reaction to occur. (Wolfe. 1994)

Zero valance iron enhanced abiotic treatment of CVOC contaminated groundwater can be applied by two methods. The treatment process may be applied in situ through the use of vertical hydraulic barriers which direct the groundwater flow through a permeable treatment zone (funnel and gate system) which contains the treatment matrix (zero valance iron, pyrite. and possibly sulfur). No secondary surface waste streams are produced by this method of application. No secondary waste, NPDES, or air permits would be needed with this system. The need for an Underground Injection Control (UIC) permit for placement of the treatment matrix needs to be evaluated

The treatment process may also be applied above ground through the recovery of the contaminated groundwater and flow through treatment canisters which contain the treatment matrix (see pump and treat section for further details regarding this method of application)

\section{Technology Application and Limitations}

Zero valance iron enhanced abiotic treatment of CVOCs may be inhibited by an elevated $\mathrm{pH}$ 
$(>8-9)$, may be inhibited by elevated nitrate levels, and may reach a dichloromethane (PDWS Maximum Contaminant Level of $5 \mathrm{ppb}$ ) endpoint in the degradation of carbon tetrachloride and chloroform Successful degradation of dichloromethane has not been shown using this technology (Orth. 1992. O'Hannesin and Gillham. 1992, O'Hannesin. 1993, Gillham. O'Hannesin, and Orth, 1993) Prior to implementation of this technology in the field. laboratory column tests and potentially pilot scale tests would be required to determine the degradation kinetics for design of a full scale facility

Application of this technology through the use of a funnel and gate system is generally limited to the depths to which vertical hydraulic barriers can be installed (generally less than 100 feet) Additionally the funnel and gate must be installed such that the groundwater plume is intercepted and directed through the treatment zone. In general this means that the groundwater flow direction must be predominately horizontal, since a vertical barrier can not intercept vertical flow. It also means that the plume must be fairly narrow and flowing in one predominant direction in order to limit the costs of barrier installation

Application of this technology through the use of pump and treat is subject to the same contaminant recovery limitations as other pump and treat treatment systems (see pump and treat section). This technology results in the degradation of CVOCs to primarily ethene, ethane, and methane. if a dichloromethane endpoint is not reached Ethene, ethane, and methane are not listed in the Primary Drinking Water Standard Other intermediates from incomplete degradation may also be present. These end products would then be present in the water discharge from the treatment process and would likely volatilize due to their high Henry's Law Constants

\section{Technology Applicability to Southern Sector Plume}

The primary contaminants associated with the Southern Sector plume are TCE and PCE (Lewis and Aadland. 1992). First order kinetic half lives of 11.5 to 66 hours and 2.9 to 25 hours for PCE and TCE respectively have been reported based upon batch and column tests at pHs ranging from 58 to 105 (decreased half lives were associated with lower $\mathrm{pHs}$ ). Dichloromethane endpoints for PCE and TCE have not been noted. The $\mathrm{pH}$ and nitrate levels in the Southern Sector groundwater are within ranges suitable for use of this technology (Orth, 1992; O'Hannesin and Gillham, 1992, O'Hannesin, 1993; Gillham, O'Hannesin, and Orth, 1993) In the area where the target concentrations are present, the contaminated groundwater is nominally 150 ' deep. the plume is fairly wide, and it flows in multiple directions, eliminating the possibility of effectively using a traditional funnel and gate treatment system. Alternative emplacement approaches would need to be developed, or the technology would have to be implemented closer to the receiving streams in much lower concentration areas. The longevity of these systems has never been fully documented. thus they represent a promising but high risk technology for the Southern Sector The application of this technology as a surface treatment, through the use of a pump and treat treatment system, is possible in the Southern Sector 
534 Airlift Recirculation Well System

\section{Technology Description}

Airlift recirculation well (ARW) treaiment of VOC contaminated groundwater is essentially an in situ air stripping process which was developed by Stanford University. ARW uses a combination of existing technologies such as air stripping. air lift pumping, and wells (Gvirtzman and Gorelick, 1992). The ARW system consists of a well with an upper and lower screen zone, an air injection blower with an associated eductor placed in the well at the lower screen zone. and vacuum removal of the off-gas at the well head. Air is injected into the eductor at the lower screen zone. As the air bubbles rise, the density of the water is decreased and an upward flow is induced. Groundwater flow into the lower screen and out the upper screen establishes a recirculation pattern. This recirculation is superimposed on the natural groundwater flow. The result is capture of the up gradient contaminant plume and multiple circulations of the contaminated water through the well for treatment. Groundwater is not brought to the ground surface, therefore there is no surface water discharge associated with ARW treatment. The width of the up gradient capture zone can be calculated with numerical, hybrid, or analytical models. As the water and air bubbles flow upward. VOCs are transferred from the water to the air phase. The off-gas removed by the vacuum at the well head can be treated prior to discharge to the atmosphere, if necessary. The ARW system is similar to the German vacuum vaporizer well (UVB) system. However, the UVB system uses a pump to lift the water in the well and provides minimal contact between the injected air and contaminated water (Herrling, et al. 1991).

Although ARW wells are normally screened in a single aquifer, it is possible to have the two screen zones in different aquifers separated by an aquitard. In this arrangement water would be withdrawn from the lower aquifer, treated within the ARW well, and discharged in the upper aquifer. This would not result in a simple pattern of recirculation and multiple circulations of the contaminated water through the well for treatment

Oxygen and nitrogen from the injected air also dissolve into the water and are transported into the aquifer. These components may be used by indigenous bacteria in the aquifer resulting in some bioremediation of VOCs. Additionally ARW wells can be used as access points to the aquifer for addition of other reactants, such as methane, to further stimulate bioremediation. Another ARW implementation that has been proposed is installation of alternate treatment technologies in the well such as zero valance iron enhanced abiotic degradation

ARW systems typically require Underground Injection Control (UIC) permits. They produce a CVOC contaminated gaseous phase which would require an Air Permit/Waiver for discharge

\section{Technology Application and Limitations}

ARW treatment (in situ air stripping) is applicable to groundwater contamination which consists of volatile organic compounds (VOCs) with high Henry's Law Constants. A single ARW well is 
capable of treating only a single aquifer zone and is not normally screened over two aquifers ARW wells can be utilized in aquifer conditions where both horizontal and vertical flow components exist. However a large vertical groundwater flow component will result in a smaller ARW well zone of influence (similar to the effects upon a recovery well).

\section{Technology Applicability to Southern Sector Plume}

The primary contaminants associated with the Southern Sector plume are TCE and PCE. TCE and PCE have Henry's Law Constants of 11 and $28 \mathrm{~L}$-atm/mol, respectively (Schwarzenbach, et al. 1993), which are suitable for ARW treatment. Because water is returned to the subsurface in an ARW, the zone of influence is smaller than that of an extraction well in a pump and treat system. This would necessitate closer horizontal spacing of ARW wells throughout the plume Interbedded and intercalated sand and clay zones make traditional application of ARW difficult in the southern sector. The potential need for alteration of the ARW technology by adding a pump to supplement the air lift. combined with careful evaluation of the flow/circulation patterns would be important elements in planning and implementing ARW in the southern sector

\subsubsection{In Situ Air Sparging (In Situ Air Stripping)}

\section{Technology Description}

In situ air sparging (IAS) is an innovative technology for the removal of VOCs from both the groundwater and the vadose zone. IAS is typically combined with soil vapor extraction (SVE) to provide greater treatment within the vadose zone and to collect the organic vapors for treatment, if necessary, prior to discharge to the atmosphere. During IAS, clean air is injected beneath the groundwater zone of contamination using either vertical or horizontal wells. The clean air typically rises through air filled channels within the saturated zone to the vadose zone ( $\mathrm{Ji}$ et al. 1993). In the vadose zone the pressure gradient produced by the SVE draws the air to the SVE well (either vertical or horizontal), where the air is brought to the surface for treatment. if necessary, and discharge. As air moves from the point of IAS injection through the air filled flow channels in the groundwater and vadose zone to the SVE well, organic compounds with large Henry's Law Constants will partition into the vapor phase. This allows VOCs present in the vadose zone and groundwater to be transported to the surface. The process may be diffusion limited (unless mixing is induced by IAS operation) due to the transport of contaminants from their point of origin to the air filled flow channels where stripping and removal occurs (Johnson et al. 1993).

Due to increases in oxygen and nitrogen concentrations within the groundwater caused by IAS. biodegradation of organic compounds may occur and therefore also be a means of organic removal associated with this technology (Ji et al., 1993; Johnson et al., 1993; and Leonard and Brown, 1992). Additionally IAS wells can be used as injection points to the aquifer for other reactants, such as methane, to further stimulate bioremediation (Hazen, et al, 1993). 
IAS systems typically require Underground Injection Control (UIC) permits. They produce a CVOC contaminated gaseous phase which would require an Air Permit/Waiver for discharge.

Technology Application and Limitations

IAS is applicable to groundwater contamination which consists of volatile organic compounds (VOCs) with high Henry's Law Constants. It is generally only applicable for treatment within water table aquifers which have high vertical air permeabilities. IAS below confining layers in the groundwater is not recommended due to the potential for lateral contaminant spread along the bottom of the confining layer and due to the difficulty of vapor phase collection. Within water table aquifers themselves, significant heterogeneities (horizontal air permeabilities much greater than vertical air permeabilities) can contribute to uncontrolled lateral contaminant spread Prior to implementation of this technology in the field, pilot scale tests would be required to determine the zone of influence of IAS wells (horizontal or vertical).

Technology Applicability to Southern Sector Plume

The primary contaminants associated with the Southern Sector plume are TCE and PCE (Lewis and Aadland, 1992). TCE and PCE have Henry's Law Constants of 10.7 and $27.5 \mathrm{~L}$-atm/mol respectively (Schwarzenbach, et al., 1993), which are suitable for IAS treatment. Significant clay lenses exist in the Southern Sector shallow aquifer zones, and the most contaminated groundwater exists in the deeper portions of the Lost Lake Aquifer zone. The confined to semiconfined nature of the Southern Sector makes the application of IAS to the southern sector difficult to successfully implement.

\subsubsection{In Situ Bioremediation}

\section{Technology Description}

In situ aerobic bioremediation of CVOC contaminated groundwater uses indigenous or added microorganisms, oxygen, substrate, and nutrients to stimulate the breakdown of the CVOCs. CVOCs are not utilized by the microorganisms, but through the process of cometabolism, they may be oxidized to carbon dioxide. During the process of cell growth organotrophic bacteria derive energy and a carbon source from the enzymatic breakdown of suitable organic molecules (substrate). These enzymes often have the ability to breakdown organic molecules other than those utilized by the bacteria for growth, such as CVOCs. In the presence of oxygen. CVOC compounds with fewer chlorine atoms (ie. vinyl chloride) generally degrade faster than those with more (ie. TCE). PCE has not been shown to degrade aerobically. Therefore, in situ aerobic bioremediation of CVOCs relies on the delivery of appropriate quantities of oxygen. substrate. and nutrients to the subsurface environment to promote the cometabolic breakdown of CVOCs (Benefield and Randall, 1985; Hazen et al., 1993; Looney and Haselow, 1993; Bramblett, et al., 1993) 
In situ anaerobic bioremediation of CVOC contaminated groundwater uses indigenous or added microorganisms. substrate, and nutrients in the absence of oxygen to stimulate the breakdown of the CVOCs. In anaerobic bioremediation CVOCs can serve as the electron acceptor during anaerobic metabolism. As such, the CVOCs are reduced and a chlorine atom is replaced with a hydrogen atom to produce a CVOC with fewer chlorine atoms than the parent compound CVOC compounds with more chlorine atoms (ie. PCE) generally degrade faster than those with fewer, resulting in the potential for the build up of vinyl chloride. In situ anaerobic bioremediation of CVOCs relies on the delivery of appropriate quantities of substrate and nutrients to the subsurface environment to promote the dechlorination of CVOCs through the anaerobic metabolic process. (Benefield and Randall, 1985; Hazen et al., 1993; Looney and Haselow, 1993, Bramblett. et al., 1993)

The potential exists to combine both aerobic and anaerobic bioremediation of CVOCs to achieve more efficient and complete bioremediation (Bramblett, et al., 1993). In fact it has been shown that within a generally aerobic subsurface environment (ie. DO $>1 \mathrm{ppm}$ ) that some anaerobic degradation. although to a lesser degree, occurs in conjunction with the more prevalent aerobic degradation (Enzien, et al., 1994)

Delivery systems for in situ bioremediation can include injection wells. IAS wells, or recirculation wells, and the added materials can be provided in either the aqueous or gaseous phases.

In situ bioremediation systems typically require Underground Injection Control (UIC) permits They typically produce no secondary waste at the ground surface unless used in combination with soil vapor extraction (SVE), in which case an Air Permit/Waiver would be required.

\section{Technology Application and Limitations}

In situ bioremediation is applicable to organic contamination which can be biologically metabolized or cometabolized to innocuous or less toxic daughter products. Appropriate bacteria. substrate. electron donors and acceptors, and nutrients must be present or added to the subsurface environment for bioremediation to occur. In most cases optimal conditions for bioremediation do not exist in the subsurface and delivery of one or more components to the subsurface environment are required. Such delivery is typically only possible into the more permeable zones (sands rather than fine grained materials). Therefore bioremediation may be mass transfer controlled. In some cases, however, motile bacteria may move into less permeable zones and decrease mass transfer limitations

Prior to implementation of this technology in the field, laboratory tests and, potentially, pilot scale tests would be required to determine the optimal additives and degradation kinetics for design of a full scale facility 


\section{Technology Applicability to Southern Sector Plume}

The primary contaminants associated with the Southern Sector plume are TCE and PCE. The TCE is generally at concentrations more than an order of magnitude greater than the PCE TCE can be degraded aerobically to carbon dioxide through cometabolism associated with methanotrophic metabolism of methane (substrate) whereas PCE can not. Such aerobic bioremediation would degrade the highest concentration contaminant. PCE can be degraded anaerobically and it has been shown that within a generally aerobic subsurface environment (ie DO $>1 \mathrm{ppm}$ ) that some anaerobic degradation, although to a lesser degree, occurs. Such combined aerobic and anaerobic biodegradation would degrade both TCE and PCE and minimizes the build up of toxic degradation products. (Enzien, et al., 1994; Hazen et al., 1993; Looney and Haselow, 1993; Bramblett, et al., 1993)

The hydraulic conductivity of the Lost Lake aquifer zone in the Southern Sector is approximately $1 \times 10^{-2} \mathrm{~cm} / \mathrm{s}$ (Hiergesell, 1993), which is appropriate for delivery of the necessary additives to promote bioremediation.

In situ bioremediation may be combined with more aggressive remediation technologies such as airlift recirculation wells or in situ air sparging to promote more efficient overall remediation (see associated sections). In the case of recirculation wells, the system could be operated in a straightforward manner by adding the necessary nutrient to the solvent stripped water in the well bore followed by release into a standard circulation cell. Alternatively, the solvents could be stripped and the nutrients could be added to the clean water in the well bore -- this treated water could be released above a semiconfining layer located between the well screens and bioremediate (utilizing indigenous microorganisms) an overlying zone (in the case of the southern sector, this might be the M Area aquifer zone which has substantially lower initial concentrations)

\subsection{Identification of Most Promising Technologies and Systems}

Table 5.1 is a matrix that summarizes the potential applicability of the technologies to the specific conditions in the southern sector of $\mathrm{A} / \mathrm{M}$ Area. For each technology, the appropriateness for Southern Sector applicability is briefly described in the categories of the hydrogeologic conditions and the contaminant plume conditions. In each of the categories, the more detailed discussion above is distilled into one, or a few, sentences that describe the key factors related to application of the technology to the Southern Sector conditions. Finally, the matrix identifies appropriate enabling technologies or actions that are necessary, or that should be evaluated, in the final process of selecting and implementing a system of technologies.

Based on the matrix, we eliminated two of the evaluated technologies from further consideration for the Southern Sector: in situ zero valance iron enhanced abiotic degradation and in situ air sparging (stripping). The plume depth and geometry is not suitable for installation and utilization of an in situ zero valence iron system. Similarly, in situ air sparging (stripping) is not 
suited to Southern Sector conditions (e.g., the depth and relatively confined nature of the core of the contaminant plume). Further, in situ air sparging is primarily a source area clean up, deriving much of its effectiveness from the vacuum extraction portion of the system. The southern sector does not have a vadose zone source and the vadose zone is expected to be "clean" at this distance from the sources in A/M Area.

Appropriate combinations of the remaining technologies appear to be the most promising approach for the Southern Sector. In particular, Natural Attenuation and Restricted Land Use appears to be an important component in any technically based corrective action for the Southern Sector Additional corrective action that targets elevated concentrations in the Southern Sector could be performed using pump and treat, airlift recirculation wells, or bioremediation (or a combination of these technologies). Based on the matrix, the list below summarizes the configuration of the most reasonable southern sector corrective action systems. The list is ordered from the more traditional systems first (simplest to implement), to the more innovative systems (possible reduced energy and operating costs):

Option A: pump and treat portions of the Southern Sector above target concentrations combined with natural attenuation and restricted land use for the remainder of the Southern Sector plume

Option B: airlift recirculation wells for portions of the Southern Sector above target concentrations combined with natural attenuation and restricted land use for the remainder of the Southern Sector plume.

Option C: airlift recirculation wells and addition of nutrients to stimulate in situ bioremediation in the formation for portions of the Southern Sector above target concentrations combined with natural attenuation and restricted land use for the remainder of the Southern Sector plume.

For all of the options, we assumed that operation of the central treatment system (M1) and the Northern Sector treatment system (A1/A2) would continue. We assumed that vadose zone remediation would be implemented near the original discharge areas. Finally, we assumed that DNAPL characterization activities will lead to appropriate expedited clean up action in the central area, and the Western, Southern, and Northern Sectors as appropriate. These activities are important because they address future contamination potential by eliminating the sources feeding the southern sector. Recommendations for evaluating the practicality and value of the various enabling technologies are provided below 


\begin{tabular}{|c|c|c|c|}
\hline Technology & Hydrogeologic Conditions & Plume Conditions & Possible Enabling Technologies or Actions \\
\hline $\begin{array}{l}\text { Natural Attenuation and } \\
\text { Restricted } I \text { and } l \text { ise }\end{array}$ & $\begin{array}{l}\text { - Conditions promote dispersion and dilution } \\
\text { - Minimal migration potential into Crouch Branch } \\
\text { Ayuifer } \\
\text { - Migration to Tims Branch and I pper Three Runs }\end{array}$ & $\begin{array}{l}\text { - Multi aquifer, large area. dilute contaminam } \\
\text { plume favorable for Natural Attenuation and } \\
\text { Restricted } 1 \text { and I Ise }\end{array}$ & $\begin{array}{l}\text {-IXOF land use management and resource decision } \\
\text { and commitment } \\
\text {-Source and hot spot remediation. and targeted } \\
\text { Southern Sector remediation is needed } \\
\text { - Alternate Concentration limits ( } A C 1 \text {.) }\end{array}$ \\
\hline Pump and Treat & $\begin{array}{l}\text { - Mass transfer limitations reduce the rate of } \\
\text { remediation to the Drinking Waler Standards } \\
\text { - Potentially requires recovery from multiple } \\
\text { aquifers throughout the entire plume, depending on } \\
\text { the target concentration level }\end{array}$ & $\begin{array}{l}\text { Potentially requires large groundwater recovery } \\
\text { rates and subsequent treatment of large columes } \\
\text { of low contaminant level water }\end{array}$ & $\begin{array}{l}\text { - Natural Antenuation and Restricted } l \text { and } l \text { ise } \\
\text { associated with the more dilute portions of the } \\
\text { plume } \\
\text {-Horizontal wells for better plume access (if } \\
\text { justified) } \\
\text { - Reinjection for hydraulic control (if justified) } \\
\text { - Low cost, low energy, low maintenance treatment } \\
\text { system }\end{array}$ \\
\hline $\begin{array}{l}\text { Zero Valance Iron Enhanced } \\
\text { Abiotic Degradation (in situ) }\end{array}$ & $\begin{array}{l}\text { - Requires near surface horizontal flow in area of } \\
\text { target concentration }\end{array}$ & $\begin{array}{l}\text { - Maximum depth of contamination is } \\
\text { approximately } 244 \mathrm{ft} \text { and the nominal depth in the } \\
\text { aquifer with the highest contamination is } \\
\text { approximately } 150 \mathrm{ft} \text {, eliminating the use of } \\
\text { traditional funnel and gate treatment systems }\end{array}$ & $\begin{array}{l}\text {-Possible use as surface treatment system for a } \\
\text { pump and treat system }\end{array}$ \\
\hline $\begin{array}{l}\text { Airlift Recirculation Well } \\
\text { System }\end{array}$ & $\begin{array}{l}\text {-Potentially requires treatment in multiple aquifers } \\
\text { throughout the entire plume (required number of } \\
\mathrm{ARW} \text { wells would probably be greater than for a } \\
\text { pump and treat system) }\end{array}$ & - In well treatment provides reasonable efficiency & $\begin{array}{l}\text { - Use as the delivery system for } \ln \text { Situ } \\
\text { Biw. mediation }\end{array}$ \\
\hline In Situ Air Sparging (Stripping) & $\begin{array}{l}\text { - AS is primarily applicable to water table } \\
\text { conditions in fairly homogeneous conditions } \\
\text { - Significant clay lenses exist creating confining to } \\
\text { semiconfining conditions making IAS difficult to } \\
\text { implement }\end{array}$ & $\begin{array}{l}\text {-Most contaminated groundwater exists in the } \\
\text { lower Lost I ake aquifer zone which is not } \\
\text { amenable to IAS because of overlying confining } \\
\text { zones }\end{array}$ & $\begin{array}{l}\text { - Poxullie to use as the delivery system for In Situ } \\
\text { Bioremediation }\end{array}$ \\
\hline In Situ Bioremediation & $\begin{array}{l}\text { - May require both aerobic and anaerobic conditions } \\
\text { in order to successfully remediate both TCE and } \\
\text { PCE } \\
\text { - } 1 \text { ost l ake aquifer zone has a hydraulic } \\
\text { conductivity amenable for delivery of the necessary } \\
\text { additives to promote bioremediation }\end{array}$ & $\begin{array}{l}\text { - Concentrations in Southerm Sector appropriate } \\
\text { for Bioremediation } \\
\text {-Chlorinated solvents require addition of a } \\
\text { primary carbon source (such as methane) }\end{array}$ & $\begin{array}{l}\text {-Possible to combine with more aggressive } \\
\text { remediation technologies such as ARW' and } 1 \mathrm{AS}\end{array}$ \\
\hline
\end{tabular}




\subsection{Recommended Confirmatory Activities}

Most of the recommended confirmatory activities are related to modeling or examination of the enhancement or enabling technologies. The results of such models would be guidance that could be used in final system configuration, design, and implementation

Option A pump and treat portions of the Southern Sector above target concentrations combined with natural attenuation and restricted land use for the remainder of the Southern Sector plume. The principal confirmatory activities would be evaluation of horizontal wells and reinjection In the case of horizontal wells, the possible installation technologies would need to be identified along with strategies to minimize installation problems (minimize drilling fluid, maintain hole stability, complete with appropriate materials, etc.) and maximize long term reliability (maintain production below the water table without a traditional filter pack). Additionally, hydrologic modeling and engineering modeling would be needed to determine if the wells provide sufficient improvement in capture and simplification in surface support facilities to justify installation costs. Because of the possible risks, reinjection would require careful modeling to justify its efficacy as a possible system enhancement. Technical, policy and regulatory evaluation are needed related to wetland enhancement. Careful evaluation of the water treatment methods proposed for use are critical to proper and efficient implementation of this option. For low to moderate concentration water, such as that in the target zone in the Southern Sector, water treatment technology should be selected with particular attention to low energy use, simplicity of operation, short and long term effectiveness, and reliability. A/M Area groundwater appears well suited to emerging advanced oxidation processes (e.g., electron beam destruction, photodegradation systems, etc.) for ex situ treatment. Recent advances in such systems have resulted in the commercial availability of relatively low cost modular systems with treatment costs in the range of $\$ 1$ to $\$ 5$ per 1000 gallons. Water treatment that result in costs far in excess of these values should be carefully examined and eliminated unless alternatively justified. A brief summary of surface water treatment technologies is provided in Table 5.2

Option B: airlift recirculation wells for portions of the Southern Sector above target concentrations combined with natural attenuation and restricted land use for the remainder of the Southern Sector plume. Hydrologic modeling of zones of capture and the circulation cells would be needed. Air treatment technologies for the dilute air stream from the recirculation wells, if required, should be carefully selected to avoid large energy costs.

Option $\mathrm{C}$ airlift recirculation wells and addition of nutrients to stimulate in situ bioremediation in the formation for portions of the Southern Sector above target concentrations combined with natural attenuation and restricted land use for the remainder of the Southern Sector plume Hydrologic modeling of zones of capture and the circulation cells would be needed. Further. microbial studies of Southern Sector groundwater and core, followed by microbial modeling in the circulation cell (or release zone) would be needed. Additional monitoring requirements associated with the microbial processes would be required during operation. Air treatment technologies, if required. for the dilute air stream from the recirculation wells should be carefully selected to avoid large energy costs. 
Table 5.2. Summary of Surface Water Treatment and Offgas Treatment Support Technologies

\begin{tabular}{|c|c|c|}
\hline $\begin{array}{l}\text { Ur Stripping } \\
\text { Offgas Treatment }\end{array}$ & $\begin{array}{l}\text { all dissolved volatile } \\
\text { organics (VOCs) }\end{array}$ & $\begin{array}{l}\text { Efficient separation technique for VOCs Overall performance depends on offgas } \\
\text { treatment selected. For low concentration VOCs in southern sector, air stripping would } \\
\text { he inefficient air stream discharged or treated by low cost low energ. offgas system } \\
\text { (e.g. sarbon) }\end{array}$ \\
\hline $\begin{array}{l}\text { 1) with ozone or } \\
\text { perwitde }\end{array}$ & $\begin{array}{l}\text { low to moderate } \\
\text { concentrations }\end{array}$ & $\begin{array}{l}\text { Commercialls available. Best performance at lou } \mathrm{pH} \text {. low TOC. low inorganic carbon. } \\
\text { etc. Costs are less than or roughly equal to other advanced oxidation methods } 1 \mathrm{eg} \\
\text { electron beam). depending on configuration. These systems may produce small amounts } \\
\text { of incomplete oxidation products Current estimates of } \mathbf{S} 1000 \text { gallons appear } \\
\text { competitive. }\end{array}$ \\
\hline clectron beam & $\begin{array}{l}\text { low in moderate } \\
\text { concentrations }\end{array}$ & $\begin{array}{l}\text { Recent commercial system demonstrated. Best performance at low } \mathrm{pH} \text {. low TOC. Iou } \\
\text { inorganic carbon. etc Costs are similar to other advanced oxidation methods. These } \\
\text { systems may produce small amounts of incomplete oxudation products long term } \\
\text { reliability not documented. Current estimates of } \$ 1000 \text { gallons appear competitive }\end{array}$ \\
\hline chemical oxidation & $\begin{array}{l}\text { low to moderate } \\
\text { concentrations }\end{array}$ & $\begin{array}{l}\text { Oxidation using chemical reagent's (e.g. Fenton's reagent). Relatively difficult to control } \\
\text { and uses large quantity of corrosive and or toxic reagents. Few well documented systems } \\
\text { implemented for low concentration VOCs in a long term groundwater treatment. }\end{array}$ \\
\hline $\begin{array}{l}\text { Lero valence tron } \\
\text { enhanced abiotic } \\
\text { de'gradation lex. } \\
\text { situ) }\end{array}$ & lou concentrations & $\begin{array}{l}\text { Innovative technology implemented on field scale to date. Potential flow rate restrictions } \\
\text { due to half lives of the chlorinated VOCs. Produces final degradation products such as } \\
\text { ethene. ethane. and methane if dechlorination is complete Commercially available. but } \\
\text { long term operation in a field setting not documented Ver. low energy costs }\end{array}$ \\
\hline broremediation & $\begin{array}{l}\text { low to moderate } \\
\text { concentrations }\end{array}$ & $\begin{array}{l}\text { Aerobic cometabolic system needed (or hybrid anaerobic-aerobic system) Currently in } \\
\text { the R\&D stage. SRS has operating pilot systems at TXX. Documentation of reliable and } \\
\text { stable long term operation in field setting not complete. }\end{array}$ \\
\hline reverse osmosis & $\begin{array}{l}\text { low to moderate } \\
\text { concentrations }\end{array}$ & $\begin{array}{l}\text { Relatively effective process: typical systems have high operating costs, high energy use. } \\
\text { and high maintenance costs. Not competitive for VOCs at this time. }\end{array}$ \\
\hline $\begin{array}{l}\text { astivated carbon } \\
\text { (aqueous phase) }\end{array}$ & low concentrations & Relatively inefficient use of carbon. Not competitive for V'OCs at this time \\
\hline $\begin{array}{l}\text { photocatalytic (e.g. } \\
\text { TiO: } \\
\text { semiconducting } \\
\text { membranes) }\end{array}$ & lou concentrations & $\begin{array}{l}\text { Innovative technology implemented on small (R\&D) scale to date Mature competitive } \\
\text { system not available at this time. }\end{array}$ \\
\hline $\begin{array}{l}\text { Chemical } \\
\text { dehalogenation }\end{array}$ & high concentrations & $\begin{array}{l}\text { Relatively expensive process Not competitive for VOC's (better for more difficult high } \\
\text { concentration wastes of organics such as PCBs) }\end{array}$ \\
\hline evaporation & $\therefore A$ & No destruction of YOCs. More expensive than air stripping and direct discharge \\
\hline $\begin{array}{l}\text { electrodialysis. } \\
\text { treeza } \\
\text { Tystallization. } \\
\text { supercritical water } \\
\text { oxidation }\end{array}$ & high concentrations & Not effective for VOCs at low concentrations \\
\hline \multicolumn{3}{|c|}{ offgas treatment methods for use with air stripping } \\
\hline \multicolumn{3}{|c|}{$\begin{array}{l}\text { Activated carbon (gas phase) hest at low. VOC loading rates. Generates secondar waste. but mas be reasonable in dilute streams } \\
\text { Catalytic oridation is good ad medium loading rates (cost penalty at low loading rates because continuous heating of all of the offgas is } \\
\text { needed). Requires new halogen resistant catalyst. } \\
\text { Incineration effective at moderate to high concentrations. but higher energy costs that catalytic oxidation. } \\
\text { VOC recovery and recycle competitive at high to very high concentrations. Requires reasonable regulatory approval of recycle } \\
\text { Free radical processes (e.g. photocatalytic, gas phase electron beam. flashlamp photolysis. corona cold plasma. ozonation. etc) are } \\
\text { innovative technologies. some relatively effective. Long term reliability not proven. Mature competitive systems not available. All free } \\
\text { radical systems tested at SRS generate small quantities of incomplete oxidation products. }\end{array}$} \\
\hline
\end{tabular}




\subsection{Summary}

Several technologies for clean up of solvents from groundwater were examined to determine the most reasonable strategy for the Southern Sector in A/M Area of SRS The most promising options identified were

Option A pump and treat portions of the Southern Sector above target concentrations combined with natural attenuation and restricted land use for the remainder of the Southern Sector plume

Option B: airlift recirculation wells for portions of the Southern Sector above target concentrations combined with natural attenuation and restricted land use for the remainder of the Southern Sector plume

Option C: airlift recirculation wells and addition of nutrients to stimulate in situ bioremediation in the formation combined with natural attenuation and restricted land use for the remainder of the Southern Sector plume

These options range from baseline/traditional methods (Option A) to more innovative technologies (Options B and $C$ ). The traditional methods would be straightforward to implement, while the innovative methods have the potential to improve efficiency and reduce long term costs. 
(10.0. 


\section{1) References}

Benefield. L D and Randall. C W (1985) Biological Process Design for Wastewater Treatment, Ibis Publishing. Charlottesville, Virginia

Bramblett. M. McCray, J. Farley, K. Falta. R, and Daniels. M (1993) "A Summary of Literature on Subsurface DNAPL Remediation," Clemson University. SCLREFF Task Order \#118. Westinghouse Savannah River Company, Aiken SC 29808

Cohen. R M and Mercer, J W (1993). DNAPL Site Evaluation CRC Press. Inc . Boca Raton. Florida

Enzien. M V. Picardal, F. Hazen, T. C., Arnold, R. G., and Fliermans, C B (1994) "Reductive Dechlorination of Trichloroethylene and Tetrachloroethylene Under Aerobic Conditions in a Sediment Column," Applied Environmental Microbiology, In Press

ESH-EMS-930098. Environmental Protection Department Environmental Monitoring Section. The Savannah River Site's Groundwater Monitoring Program. Third Quarter 1993 (U), February. 1994. Westinghouse Savannah River Company, Aiken SC 29808

ESH-EMS-930262, Environmental Protection Department Environmental Monitoring Section. Emironmental Protection Department's Well Inventory. March 1994. Westinghouse Savannah River Company, Aiken SC 29808.

Gillham. R. W. O'Hannesin, S F., and Orth, W. S (1993). "Metal Enhanced Abiotic Degradation of Halogenated Aliphatics: Laboratory Tests and Field Trials." HazMat Central Conference. Chicago. Illinois, March 9-11

Gvirtzman. H and Gorelick, S. M. (1992). "The Concept of In-Situ Vapor Stripping for Removing VOCs from Groundwater." Transport in Porous Media, 8.71-92

Hazardous Waste News. (1994). "Around the States - Florida," May 9. pp 149

Hazen, T. C, Looney, B. B , Enzien. M., Franck. M. M., Fliermans, C. B , and Eddy. C A (1993) "In Situ Bioremediation Via Horizontal Wells," I\&EC Special Symposium. American Chemical Society, Atlanta, GA, September 27-29

Herrling. B. Stamm. J., and Alesi, E. J. (1991). "In-Situ Groundwater Remediation of Strippable Contaminants by Vacuum Vaporizer Wells (UVB): Operation of the Well and Report about Cleaned Industrial Sites." Proc. Third Forum on Innovative Hazardous Waste Treatment Technologies Domestic and International, sponsored by the U S. EPA. June, 1991. Dallas. T.X 
Hiergersell. R A (1993) "Hydrologic Analysis of Data for the Lost Lake Aquifer Zone of the Steed Pond Aquifer at Recovery Well RWM-16 (U)." WSRC-TR-92-529. Rev 1. Westinghouse Savannah River Company. Aiken SC 29808

Ji. W . Dahmani, A. Ahlfeld. D P , Lin. J D. and Hill, E (1993) "Laboratory Study of Air Sparging Air Flow Visualization," Ground Water Monitoring \& Remediation, Vol 13, No 4. pp $115-126$

Johnson, R L. Johnson, P. C., McWhorter, D B. Hinchee, R E., and Goodman, I (1993) "An Overview of In Situ Air Sparging." Ground Water Monitoring \& Remediation, Vol 13. No 4. pp 127-135

Leonard. W C and Brown, R. A. (1992) "Air Sparging: An Optimal Solution." Proceeding of the 1992 Petroleum Hydrocarbons and Organic Chemicals in Ground Water Prevention.

Detection, and Restoration. National Ground Water Association, Dublin, Ohio, pp. 349-363

Lewis, S E and Aadland. R. K. (1992). "Hydrogeologic Setting of A/M Area Framework for Groundwater Transport (U)," WSRC-TR-92-355, Westinghouse Savannah River Company, Aiken SC 29808

Looney, B B and Haselow. J S (1993). "Mixed Waste Management Facility Alternate Corrective Action Plan: Groundwater Remediation Technology Selection (U)," WSRC-RP-931377. Westinghouse Savannah River Company, Aiken SC 29808

Marine, I. W and Bledsoe, H. W. (1984). M Area Groundwater Investigation, Supplemental Technical Data Summary. DPSTD-84-112. Westinghouse Savannah River Company. Aiken SC 29808

O'Hannesin, S F and Gillham, R. W. (1992). "A Permeable Reaction Wall for In Situ Degradation of Halogenated Organic Compounds." $45^{\text {th }}$ CGS Conference, Toronto, Ontario. October 25-28

O'Hannesin. S F (1993). "A Field Demonstration of a Permeable Reaction Wall for the In Situ Abiotic Degradation of Halogenated Aliphatic Organic Compounds," thesis presented to the Iniversity of Waterloo in partial fulfillment of the requirements for the degree of Master of Science

Orth, W S. (1992). "Mass Balance of the Degradation of Trichloroethylene in the Presence of Iron Filings." thesis presented to the University of Waterloo in partial fulfillment of the requirements for the degree of Master of Science.

Rehder. T. E. (1992). "Southern Sector Groundwater Remediation, Air Abatement Alternatives." WSRC-RP-92-584, Westinghouse Savannah River Company, Aiken SC 29808 
Schwarzenbach, R P. Gschwend, P M , and Imboden, D M (1993) Environmental Organic Chemistry John Wiley \& Sons. Inc., New York

South Carolina Hazardous Waste Management Regulation R61-79 26494

Wolfe. L (1994) April 7 personal correspondence. U. EPA Environmental Research Laboratory at Athens. GA

WSRC (1990) Assessing DNAPL Contamination. A/M Area. Savannah River Site Phase I Results WSRC-RP-92-1302, Westinghouse Savannah River Company, Aiken SC 29808 

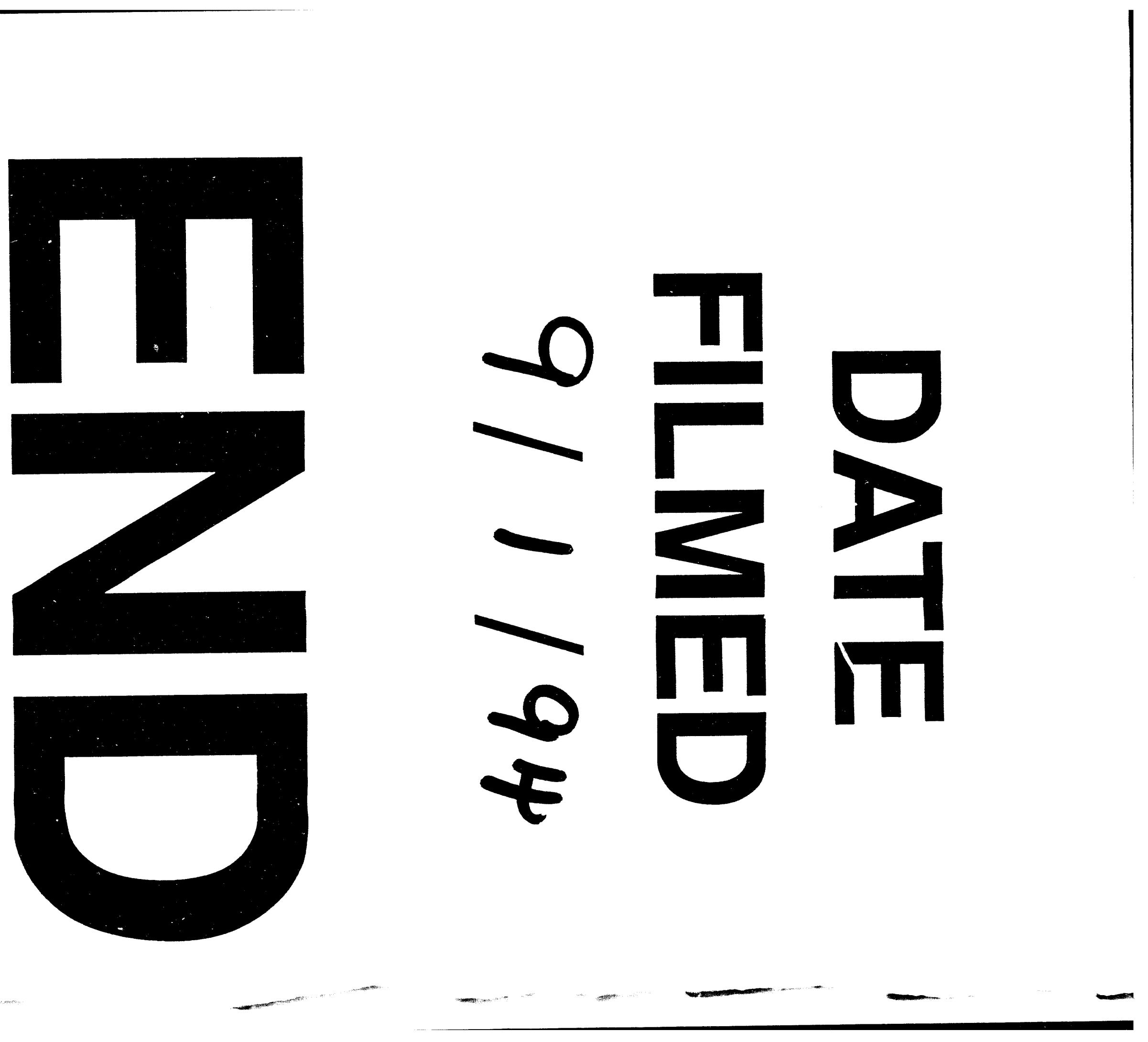